\title{
Filter-feeding in fifteen marine ectoprocts (Bryozoa): particle capture and water pumping
}

\author{
Hans Ulrik Riisgård ${ }^{1}$, Patricio Manríquez ${ }^{2}$ \\ ${ }^{1}$ Institute of Biology, Odense University, Campusvej 55, DK-5230 Odense M, Denmark \\ ${ }^{2}$ School of Biological Sciences, University of Wales, Bangor, Gwynedd LL57 2UW, United Kingdom
}

\begin{abstract}
The particle capture mechanism in ectoprocts was described, and the pumping rates in 15 species of marine ectoprocts with divergent Jophophore morphometry were quantified in order to comprehend and characterize the lophophore as a filter-pump. Further, the effects of algal concentration and temperature on clearance were studied. The most characteristic feature of particle capture, apparent from video recordings, was that when the path of a particle was altered from downwards, towards the mouth, to outwards, between the tentacles, the particle was stopped by a tentacle. In most species fbut never in Crisia eburnea which lacks frontal cilia) some of the trapped particles were seen to move along the tentacle surface towards the mouth. But more frequently, another downward transport mechanism was involved. As a result of the action of tentacle flicking restrained particles were propelled back into the central lophophore current to be carried further downwards, perhaps to be restrained by a tentacle again. These observations, supplemented with theoretical calculations, support the assumption that a mechanical laterofrontal-filter is at work which filters the water while the central current, created by the special lophophore pump-design, together with the flicking action of the tentacles, cleans the filter and transport the particles towards the mouth. Also, the measured particle retention efficiency, expressed as simultaneous clearance of particles of different sizes offered as a mixture of flagellates, supports the assumption of the presence of a mechanical laterofrontal-filter in the ectoprocts. The video recordings of particle trajectories revealed that there is a velocity profile at the lophophore entrance, the highest velocities being found in the central part of the lophophore. Thus, the mean velocity through the central area of the feeding core and the velocity through the outer area was used to estimate the pumping rates of ectoprocts. The pumping rate was found to vary between the 15 species, from $0.14 \mathrm{ml} \mathrm{h}^{-1}$ zooid $^{-1}$ in C. eburnea to $7.5 \mathrm{ml} \mathrm{h}^{-1}$ in Flustrellidra hispida. The pumping rates $\left(\mathrm{Q}, \mathrm{ml} \mathrm{h}^{-1} \mathrm{zoold}^{-1} ; 20^{\circ} \mathrm{C}\right)$ of all examined species as a function of the total lophophore tentacle length $(N L, \mathrm{~cm})$ was expressed by the equation: $Q=3.390 N L-0.704$. A linear relationship between tentacle length specific pumping rate and total tentacle length indicates that the ciliary pump in small lophophores such as that of $C$. eburnea is relatively weak compared to large lophophores as found for example in F. hispida. The maximum zooida] clearance rates $(F)$ of $C$. hyalina at 10,15 and $20^{\circ} \mathrm{C}$, measured after an initial stimulating period, was $0.12,0.16$ and $0.17 \mathrm{ml} \mathrm{min}^{-1}$ zoold $^{-1}$, respectively. The ratio $F / Q$ showed that about $40 \%$ of the water pumped through the lophophore entrance may subsequently pass through the laterofrontal filter
\end{abstract}

KEY WORDS: Pumping rates - Clearance - Lophophore morphometry Filter-pump - Particle trajectories Tentacle flicking Laterofrontal-filter . Retention efficiency Effects of algal concentration and temperature

\section{INTRODUCTION}

In the suspension-feeding ectoprocts, which were earlier regarded as the only group of true bryozoans (Nielsen 1987, 1995; but see Ryland 1976, Willmer 1990, Hayward \& Ryland 1995), the feeding apparatus consists of a ring of extended ciliated tentacles which form a tentacular crown or lophophore, with the mouth at the centre of its base (Fig. 1A). In some species the lophophore is shaped like an inverted cone or bell with the tips of the tentacles bent outwards (Ryland 1976 . Winston 1978)

The form of the tentacles is more or less triangular in cross-section with the frontal tip facing inwards. For example in Cryptosula pallasina the frontal-abfrontal height is about $30 \mu \mathrm{m}$ while the width at the abfrontal side is approximately $20 \mu \mathrm{m}$ (Gordon 1974), but smaller dimensions may be found in other ectoprocts; 


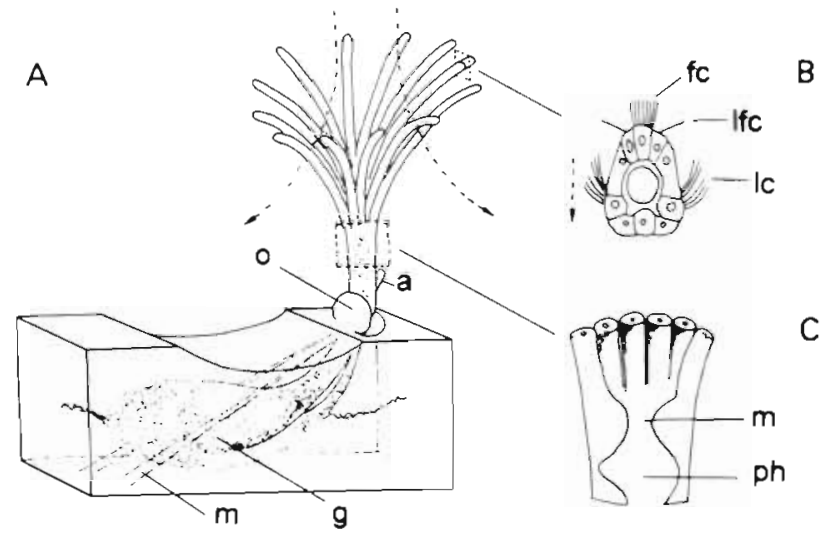

Fig. 1 (A) Individual feeding unit of an anascan ectoproct colony (autozooid) with a ring of extended ciliated tentacles forming a crown (lophophore), which can be withdrawn into a protective house-box (zooecium) by means of retractor muscles $(m)$ through an upper lid (operculum, o). The gut $(g)$ is strongly looped and the anus (a) opens just outside the lophophore. (B) Transverse section of tentacle with water pumping lateral cilia (lc), laterofrontal cilia (lfc) and frontal cilia (fc). (C) Longitudinal section through lowest part of lophophore showing the open mouth $(\mathrm{m})$ and the pharynx (ph). Water currents are indicated with dashed arrows

thus $13 \times 9 \mu \mathrm{m}$ may apply for Electra pilosa (Lutaud 1973). The dimensions vary somewhat in the distal or basal regions of the tentacles, and the relative dimensions of tentacles also varies amongst species (Atkins 1933, Winston 1978).

The parameters of the lophophore have been summarized by Gordon et al. (1987). For example, the number of tentacles in marine ectoprocts may vary from 8 to 40 , the length of the tentacles from 124 to $929 \mu \mathrm{m}$, and the diameters of the open Iophophores from 187 to $1420 \mu \mathrm{m}$. Further, the number of tentacles may vary somewhat within the same species dependent on nutrition (Jebram 1979, Thorpe et al. 1986), and the tentacles tend to be shorter and fewer in younger zooids (Gordon 1974, Cadman \& Ryland 1996). Recently, it has been found that extended duration of larval swimming may result in a marked decrease in ancestrular lophophore size (Wendt 1996).

Three types of ciliary rows may be found on the tentacles: lateral-, frontal- and laterofrontal (Fig. 1B). The lateral cilia near the abfrontal surface of the tentacles are about $25 \mu \mathrm{m}$ long and beat from the frontal to the abfrontal surface (Gordon 1974). The lateral cilia are the main water-current producing cilia. They beat metachronally and the waves pass up one side of the tentacle and down the other at right angles to the direction of beat of the cilia. Thus, the waves move clockwise when the animal is viewed from above (laeoplectic metachronism; Nielsen 1971, 1987). The development of the cilia along the frontal surface varies widely in different species. They may be absent as in Crisia and Heteropora sp. (Nielsen 1987, see Fig. 21B therein), rudimentary as in Lichenopora fimbriata (Atkins 1933), short and few as in Electra and Membranipora sp. (Atkins 1933, Gilmour 1978), or numerous and long as in Flustrellidra hispida (Atkins 1933). In the first case a frontal current along the length of the tentacle is obviously absent. The role of the frontal cilia in feeding is therefore doubtful and it has been assumed that these cilia play an inferior role in the particle capture process (Nielsen 1971). Near the mouth, where the tentacles are crowded together (Gordon 1974), the frontal cilia may be especially long while the lateral cilia are reduced in length (Atkins 1933). The function of the frontal cilia, especially of those close to the bases of the tentacles, may be to help to produce and direct the main water current towards the mouth. There the muscular pharynx (Fig. 1C) acts as a suction-pump which eventually receives the food particles.

The water current produced by the lateral cilia passes between the tentacles outwards. This results in the formation of a central stream directed straight down the lophophore to the mouth (Ryland 1976. Best $\&$ Thorpe 1983, 1986). The particle capture mechanism is not adequately described, but the single row of stiff laterofrontal cilia, about $20 \mu \mathrm{m}$ long at intervals of approximately $5 \mathrm{\mu m}$ (Gordon 1974, Winston 1978, Nielsen 1987), may affect particle capture either as sensors (to detect the presence of particles in the water and initiate tentacle flick or reversal of lateral cilia) or act as a sieve which restrains the suspended food particles (Bullivant 1968a). Hitherto, no conclusive experimental studies have been carried out to verify the sieving theory, and other suggestions for explaining the capture process have been proposed (Strathmann 1973, 1982, Gilmour 1978, Best \& Thorpe 1983). Gordon et al. (1987) have summarized the conflicting hypotheses concerning particle retention. The prevailing view seems to be that particles are retained upstream from the lateral cilia by means of a local reversal of beat of the lateral cilia (but see Mukai et al. 1997). Further, the retention mechanism has not been regarded as very efficient because many particles escape with the water current passing out between the tentacles in the upper part of the lophophore.

A number of attempts have been made to quantify the volumes of water processed per unit time in ectoprocts. By measuring the rate of change in concentration of suspended algal cells in a closed container with whole colonies of ectoprocts, the zooidal clearance rates have been determined by several workers (Bulivant 1968a, Menon 1974, Muñoz \& Cancino 1989, Riisgård \& Goldson unpubl.). Strathmann (1973) estimated clearance rates by measuring particle movements past dissected lophophores, while other research workers 
have measured particle velocities in intact individual zooids and subsequently calculated the pumping rate as the product of cross-sectional area of the lophophore entrance and particle velocity (Best \& Thorpe 1983, 1986, Sanderson et al. 1994, Sanderson \& Thorpe 1996). The literature on particulate feeding and lophophore currents has been reviewed by Winston (1977), Gordon et al. (1987), and later more briefly by McKinney (1990), but the actual extent of conflicting experimental data in the literature was not always realized and pointed out

The purpose of the present work was to describe the particle capture mechanism in ectoprocts, and further to quantify the pumping rates in different species of ectoprocts with divergent lophophore morphometry in order to comprehend and characterize the lophophore as a filter-pump.

\section{MATERIALS AND METHODS}

Experimental animals. The present work deals with 15 species of ectoprocts belonging to different systematic groups of bryozoans (see Table 1 for an overview). Particle clearance experiments were exclusively per-

Table 1. Overview of exammed species and index number (\#) used in the present work

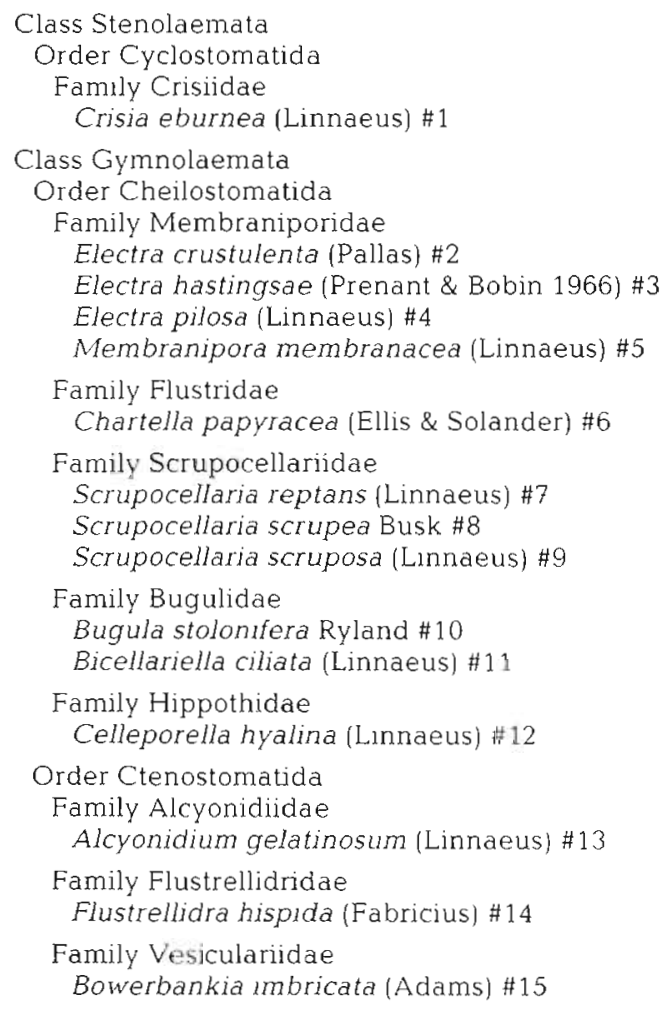

formed with Celleporella hyalina cultivated on pieces of plastic strips whereas video recordings were carried out on all species in order to study the particle capture process and to quantify the water pumping rate of the lophophore.

Cultivation of Celleporella hyalina. Colonies of Celleporella hyalina attached to fronds of Fucus serratus were collected in the Menai Straits at Beaumaris, North Wales, UK, brought to the laboratory (School of Biological Sciences, SBS, University of Wales, Bangor), submersed in seawater $\left(16^{\circ} \mathrm{C}\right)$ and kept in darkness. After $72 \mathrm{~h}$ pieces of $F$. serratus heavily encrusted with C. hyalina were placed in a plastic container filled with $0.2 \mu \mathrm{m}$ filtered and aerated seawater. Larval release was induced by exposing the colonies to light. Acetate sheets previously conditioned in running seawater were used as settlement substrata. After a week the acetate sheets were removed from the container and small pieces of acetate with young colonies of 3 or 4 zooids were cut off and adhered individually to clean $7 \times 4 \mathrm{~cm}$ pieces of acetate sheets using superglue. Each sheet was placed in $300 \mathrm{ml}$ vials filled with filtered seawater and water movement was provided by an oscillating paddle system. The colonies were fed abundantly with Rhinomonas reticulata (formally Rhodomonas baltica, see Novarino 1992) according to Hunter \& Hughes (1993) The water in the vials was changed every second day and the colonies were cleaned with the aid of a soft brush.

Collection and storage of ectoprocts. Most of the ectoproct species used in the present work (for exceptions see below) were collected at low tide from the rocky intertidal zone in the Menai Strait near the Menai Bridge, and at Rhosneigr, North Wales, UK. Ectoprocts were found on fronds of seaweed (Fucus serratus, Laminaria saccharina, Ascophyllum nodosum, Ceramium sp.), which were often heavily encrusted with colonies, or we searched for ectoprocts between the holdfasts of macro-algae, on smaller stones and in rock crevices. Upon arrival at the laboratory the material was cleaned and kept in a container with filtered $(0.2 \mu \mathrm{m})$ and aerated seawater $(34 \%$ S). The day after collection the ectoprocts were identified to species and representative samples were placed in smaller containers with filtered seawater, $5 \times 10^{3}$ Rhinomonas reticulata cells $\mathrm{ml}^{-1}$ were added and the samples were kept in a thermoregulated bath $\left(15^{\circ} \mathrm{C}\right)$ until analyses could take place during the period September to November 1996.

Bicellariella ciliata was collected from bottom material trawled at $20 \mathrm{~m}$ water depth in Red Wharf Bay off northeast Anglesey, UK. Electra crustulenta and E. hastingsae were collected on Fucus serratus in Kerteminde Fjord, Denmark, and video recordings (see later) were performed at $20 \% \mathrm{~S}$ and $20^{\circ} \mathrm{C}$ at the 
Fjord Biology Laboratory, Kerteminde, Denmark, in May to July 1996.

Clearance measurements. The clearance rate was measured as the volume of water cleared of algal cells per unit time. Algal cells were added to a strongly aerated glass beaker with a known volume of water ( $V=$ $300 \mathrm{ml}$ ) and with 4 colonies of Celleporella hyalina growing on the surface of a plastic strip which was mounted on the inside wall of the beaker. The transparency of both the strip and the beaker allowed observation of the colonies to determine if the lophophores were out Colonies were starved $24 \mathrm{~h}$ previous to the clearance measurements. The reduction in the number of algal cells as a function of time was followed by taking samples (15 ml) every $5 \mathrm{~min}$ and measuring the algal concentration with an electronic particle counter (Elzone model 80 xy fitted with a $76 \mu \mathrm{m}$ orifice tube usable for particles between approximately 3 and $30 \mu \mathrm{m}$ ). Afterwards, the remaining water (about $13 \mathrm{ml}$ ) was immediately returned to the experimental beaker to ensure only an insignificant reduction in the volume of water. Clearance (Cl) was determined from the exponential reduction in algal cell concentration using the formula: $\mathrm{Cl}=$ $(V / n t) \ln \left(C_{0} / C_{t}\right)$, where $C_{0}$ and $C_{\text {t }}$ are the algal concentrations at time 0 and time $t$, respectively, and $n=$ number of zooids counted under a stereo-microscope as the number of zooids containing algal pigment inside the gut (i.e. they have been actively feeding during the experiment). The exponential reduction in algal cell concentration was followed and verified as a straight line in a semilog plot made during the experiment.

The clearance capacity of Celleporella hyalina at low algal concentration as well as the effects of temperature and the response to various algal concentrations were examined by using Rhinomonas reticulata. Particle retention efficiency was examined by simultaneous measurement of the clearance of variously sized flagellates (Isochrysis galbana: mean diameter $=4.4 \mu \mathrm{m}$, range 3.3 to $5.6 \mu \mathrm{m} ; R$. reticulata: $6.8 \mu \mathrm{m}$,

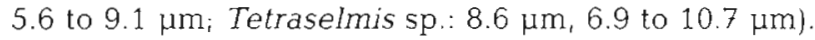

Video recordings. Particle paths and velocities were recorded at $20^{\circ} \mathrm{C}$ using a video camera (Kappa CF $11 / 1$ ) attached to an inverted microscope (Labovert FS), and a 50 half-frames per second video recorder (Panasonic NV-FS200 HQ). Video frames could be copied by means of a video graphic printer (Sony UP$860 \mathrm{CE}$ ). For bryozoan zooids forming a continuous encrusting layer the following method was employed: Using a scalpel, a thin strip of the ectoproct colony and its substratum was cut off, preferably with only a few rows of zooids, and the strip was bent at an angle of 45 to $90^{\circ}$. Later (after a recovery period of a few days) the bent strip of zooids was placed in a vertical position in a $10 \mathrm{ml}$ observation chamber of the inverted microscope. This ensured a side-view of the extended lopho- phores. In the case of erect ectoproct colonies a small bundle of the colony was placed on the bottom of the observation chamber and zooids in appropriate sideview positions were selected for video recordings. In all cases the lophophores to be studied were raised at least $200 \mu \mathrm{m}$ above the bottom of the observation chamber to avoid wall interference. The microscope was adjusted to bring particles travelling in the central current of the lophophore into focus.

The relative movements of particles, usually Rhinomonas reticulata at a concentration of about $3 \times$ $10^{3}$ cells $\mathrm{ml}^{-1}$, added to the observation chamber were recorded and the position of the particles in the successive frames traced. Often this was done by mounting a transparent plastic sheet on to the video screen so that the tentacle contours as well as the position of suspended particles could be marked with a pen directly on the sheet frame by frame, usually with time intervals of $0.02 \mathrm{~s}$. Thus, both the particles paths and their velocities could be determined and related to the morphology of the lophophore.

\section{RESULTS}

\section{Clearance experiments}

A number of clearance experiments were performed in order to examine the effects of algal concentration and temperature on the clearance rate in Celleporella hyalina. This was done in order to identify a reference state to be used in later experiments, and for comparisons with video recordings.

Effects of algal concentration

Fig. 2A shows the effect of increasing the algal concentration from about $5 \times 10^{3}$ Rhinomonas reticulata cells $\mathrm{ml}^{-1}$ to $10^{5}$ cells $\mathrm{ml}^{-1}$ and then replacing the water with new water having a concentration of $10^{4}$ cells $\mathrm{ml}^{-1}$. Clearance immediately ceased at the high algal concentration, but slowly returned to the original rate when the algal concentration became low again. This phenomenon may be explained by a rapid filling up of the gut ('satiation') in water with a very high algal concentration followed by a slow recovery of the clearance rate in new water with a considerably lower concentration of algae.

\section{Effects of temperature}

When the water temperature was decreased from 10 to $5^{\circ} \mathrm{C}$, the clearance rate became zero, Fig. $2 \mathrm{~B}$ 


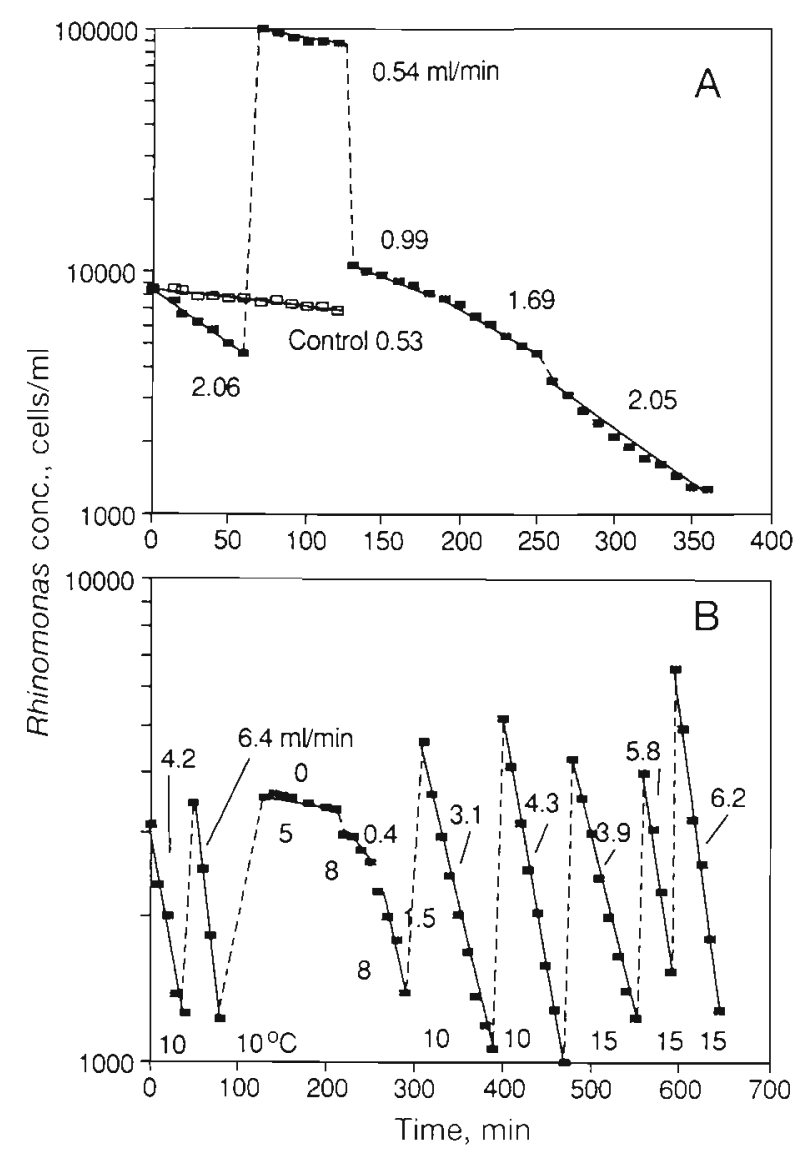

Fig. 2. Celleporella hyalina. (A) Reduction in algal cell concentration due to filter feeding by 4 colonies of ectoprocts in an aerated beaker The first vertical dashed line (from left) indicates addition of supplementary algal cells to make a high concentration, whereas the second dashed line indicates change of water to re-establish the initial algal concentration. The sedimentation rate in a control without colonies is also indicated. The clearance rates $\left(\mathrm{ml} \mathrm{min}{ }^{-1}\right)$ of the colonies are indicated. (B) Reduction in algal cell concentration at different temperatures. Dashed lines indicate addition of algal cells. The estimated total clearance rates $\left(\mathrm{ml} \mathrm{min}{ }^{-1}\right)$ of the colonies (corrected for sedimentation) are indicated above regression lines along with the various experimental temperatures $\left({ }^{\circ} \mathrm{C}\right)$ indicated below the lines

(note: the slight reduction in algal concentration was due to sedimentation). When the temperature was increased first to $8^{\circ} \mathrm{C}$, and then later on to 10 and $15^{\circ} \mathrm{C}$, the clearance rate quickly resumed its original high value. The interruption of the clearance at $5^{\circ} \mathrm{C}$ can be ascribed to closing of the zooids (as observed during the experiment). It is notable that the clearance rate increased with the exposure time to both algae (i.e. possible stimulating effect due to more active zooids and/or increased pumping activity due to higher beat frequency of the lateral cilia) and higher temperature (i.e. adaptation to a new temperature and/or more active zooids).

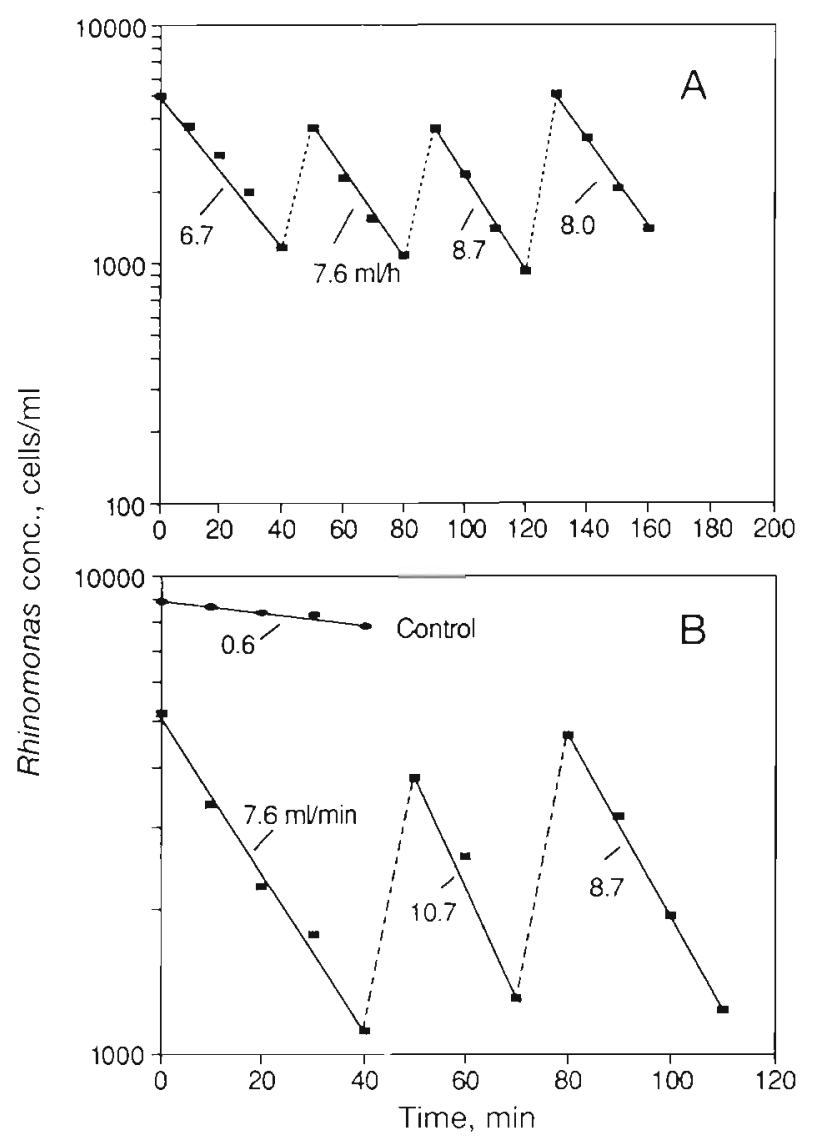

Fig. 3. Celleporella hyalina. Maximum colony clearance rates at (A) $15^{\circ} \mathrm{C}$ and (B) $20^{\circ} \mathrm{C}$ obtained after about $1 \mathrm{~h}$ at maintained low algal concentrations. The colonies had been kept at the experimental temperatures for about $24 \mathrm{~h}$ previous to the measurements

The phenomenon of stimulation after first addition of algae was also seen in the clearance experiments shown in Fig. 3. In these experiments the zooids had been starved overnight at a constant temperature of either 15 or $20^{\circ} \mathrm{C}$. The high clearance rates obtained after the initial stimulating period represent the clearance capacity (or maximum clearance rate) which should be used as the reference state, as shown in Table 2, which states the maximum clearance values per zooid measured at 10,15 and $20^{\circ} \mathrm{C}$.

\section{Particle retention efficiency}

Fig. 4 shows simultaneous clearance of particles of different size prepared as a mixture of flagellates (Isochrysis galbana, Rhinomonas reticulata and Tetraselmis sp.). Data from this and similar experiments have been used to appraise particle retention efficiency. For comparison, all clearance rates were expressed as percent of the clearance rate of the 
Table 2. Celleporella hyalina. Maximum clearance rates $( \pm \mathrm{SD}$ ) obtained in experiments using 4 colonies with a total number of 3264 actively feeding zooids

\begin{tabular}{|c|c|c|}
\hline $\begin{array}{c}\text { Temperature } \\
\left({ }^{\circ} \mathrm{C}\right)\end{array}$ & $\begin{array}{c}\text { Clearance } \\
\left(\mathrm{ml} \mathrm{min}^{-1} \text { colony } y^{-1}\right)\end{array}$ & $\begin{array}{c}\text { Clearance } \\
\left(\mathrm{ml} \mathrm{h}^{-1} \text { zooid }^{-1}\right)\end{array}$ \\
\hline 10 & $6.4^{\mathrm{d}}$ & 0.12 \\
\hline 15 & $8.1 \pm 0.6^{b}$ & 0.16 \\
\hline 20 & $9.1 \pm 1.4^{c}$ & 0.17 \\
\hline \multicolumn{3}{|c|}{$\begin{array}{l}\text { a Data from Fig. } 2 B \text { (second clearance value) } \\
\text { bData from Fig. 3A (last } 3 \text { values) } \\
\text { "Data from Fig. 3B (last } 2 \text { values) }\end{array}$} \\
\hline
\end{tabular}

largest particle size in each experimental series. A plot of the data is shown in Fig. 5. This figure shows that particle retention efficiency falls rapidly when particle diameter is below $6 \mu \mathrm{m}$. The plateau indicates that the clearance rate for particles above approximately $6 \mu \mathrm{m}$ represents the true filtration rate (i.e. the volume of water actually passing through the assumed laterofrontal-filter, hereafter designated $F$ ). This means that particles $>6 \mu \mathrm{m}$ may be retained with almost $100 \%$ efficiency whereas practically all particles $<5$ $\mu \mathrm{m}$ pass through the filter.

The low clearance rate at the end of the experimental period depicted in Fig. 4 was presumably due to 'satiation' of the feeding system (cf, previous comments with respect to Fig. $2 \mathrm{~A}$ ). This phenomenon may also explain the reduction from $4.7 \mathrm{ml} \mathrm{min}^{-1}$ in the first $20 \mathrm{~min}$ to $2.0 \mathrm{ml} \mathrm{min}{ }^{-1}$ in the following $60 \mathrm{~min}$.

\section{Flow patterns and current velocities}

The flow pattern in the region of the ectoproct lophophores of 6 species and velocity distributions are illustrated in Figs. $6 \&$ 7. These examples serve to illustrate some common features that apply to ecto-

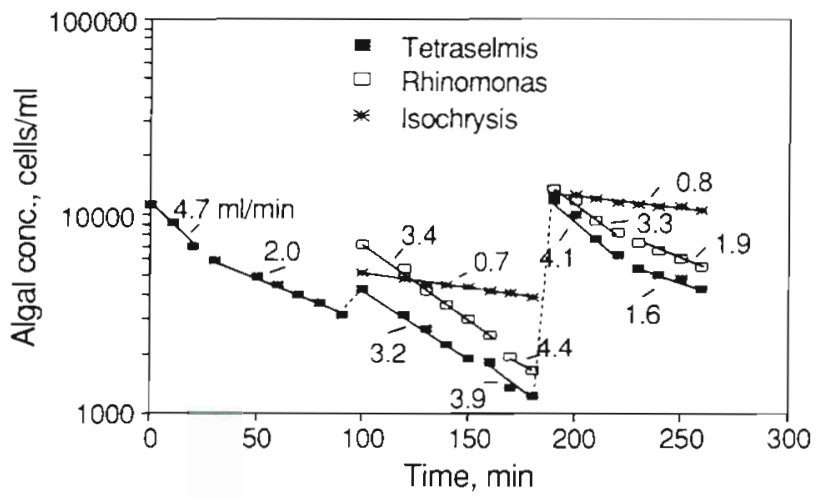

Fig. 4. Celleporella hyalina. Simultaneous reduction in concentration of 3 different-sized algal cells (Tetraselmis sp., Rhinomonas reticulata, Isochrysis galbanal. The estimated total colony clearance rates of the different cells are indicated

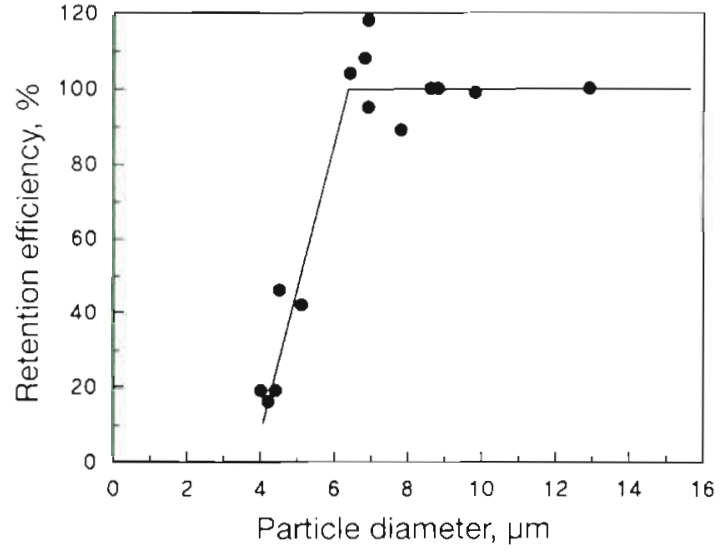

Fig. 5. Celleporella hyalina. Particle retention efficiency

proct filter-pumps: particles in a certain region above the animal, defined by a distance corresponding to at least 1 tentacle length, are accelerated towards the entrance of the lophophore, and the particles gain their highest velocity somewhat inside the 'funnel'. Further, the velocity distribution at the entrance shows that the particle velocity is highest in the central core, ranging from $1.78 \pm 0.31 \mathrm{~mm} \mathrm{~s}^{-1}$ in Crisia eburnea to $3.11 \pm 0.61$ in Alcyonodium gelatinosus, and decreases to about half that at the entrance periphery. The exit speed of uncaptured particles, exiting the lophophore particularly in the upper region, is 1 to $1.3 \mathrm{~mm} \mathrm{~s}^{-1}$.

\section{Particle capture in the lophophore}

The most characteristic feature of particle capture, based on the video recordings, was that the path of a particle entering the lophophore was altered from downwards (towards the mouth) to outwards (between the tentacles). Apparently, the alteration of course slowed down the speed, but this may partly be an illusion owing to a wide depth of focus in the microscope. After the path of the particle had been altered, the particle impacted and stuck to a tentacle for varied periods of time (often up to 25 video frames, or half a second. but sometimes considerably longer) before it, in some cases, was carried downwards. In some of the 15 species of ectoprocts examined, particles were seen to move steadily down the tentacle surface, due to frontal ciliary action, towards the mouth. In, for example, Flustrellidra hispida retained particles moved downwards on the frontal surface of the tentacles with a velocity of about $2.5 \mathrm{~mm} \mathrm{~s}^{-1}$ (Fig. 8) whereas the speed was only about $0.5 \mathrm{~mm} \mathrm{~s}^{-1}$ in Membranipora membranacea. More frequently, however, another downward transport mechanism was involved. Due to the action of tentacle flicking (Figs. $9 \& 10$ ) stuck particles were 
Fig. 6. Flow pattern in the region of the lophophore of (A \& B) Crisia eburnea and (C \& D) Celleporella hyalind obtained by means of videorecording. Flow lines and velocitıes of particles $\left(\mathrm{mm} \mathrm{s}^{-1}\right.$, based on a time interval of $0.02 \mathrm{~s}$ between subsequent video frames) are indicated. Scale bars $=100 \mu \mathrm{m}$
A

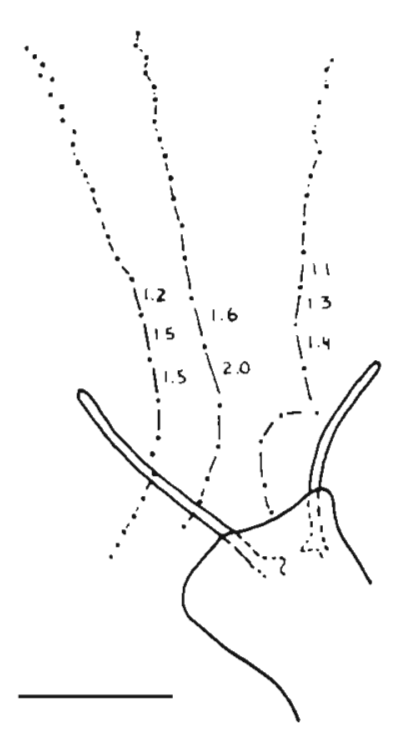

B

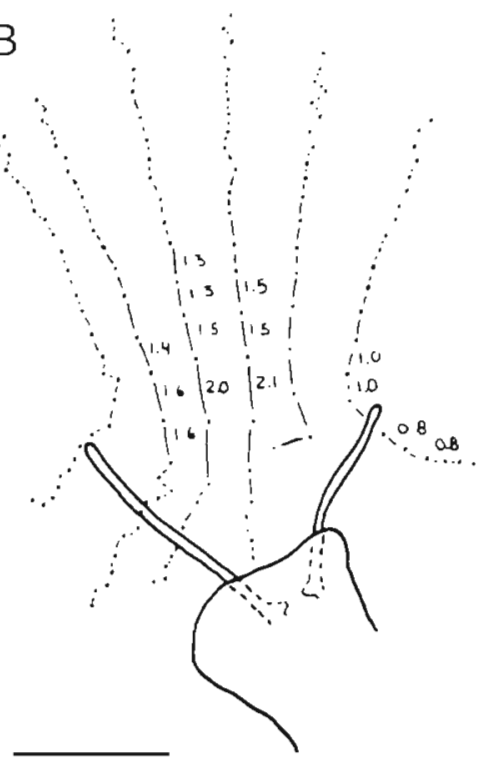

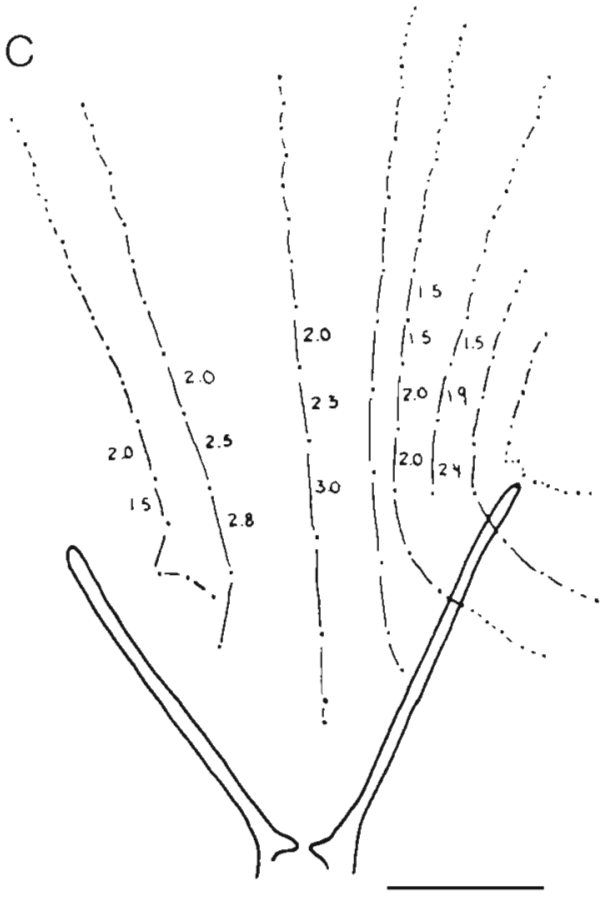

often seen to be conveyed back into the central lophophore current to be carried further downwards, perhaps to be retained again by a tentacle. Thus, flicking assists the transport of retained particles back into the central current, but particles approaching a flicking tentacle were also sometimes seen to be pushed inwards into the central current. The present observations support the assumption that a laterofrontal-filter filters the water while the central current (created

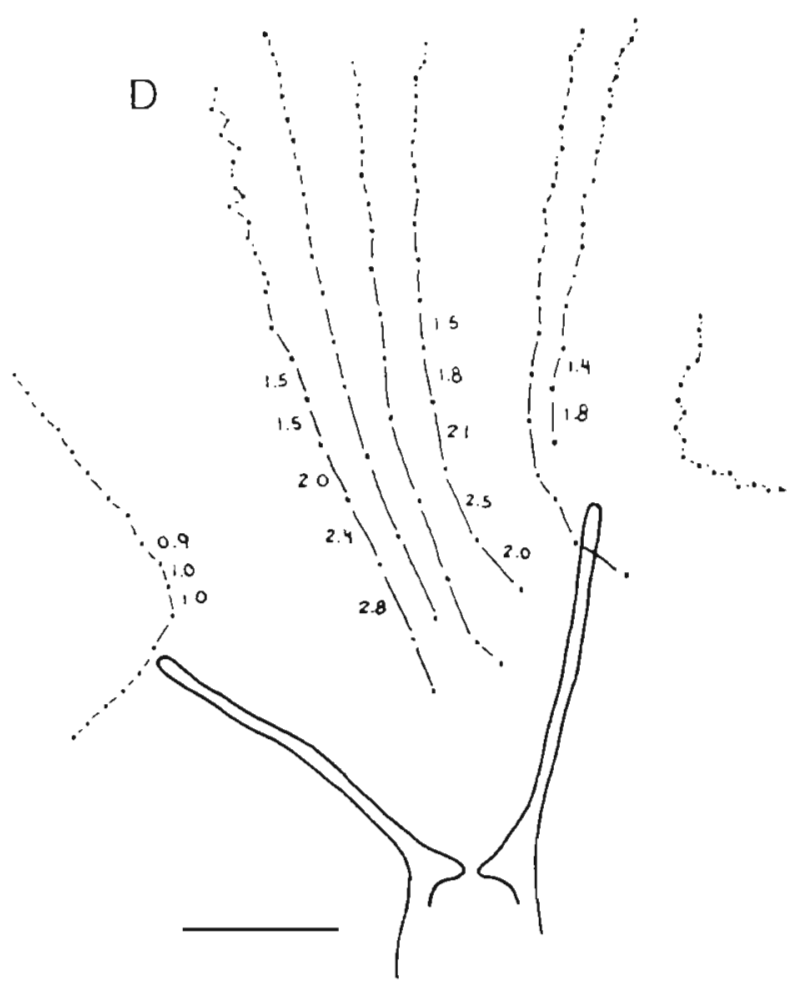

by the special lophophore pump-design) and the action of flicking tentacles in co-operation clean the filter and transport the particles toward the mouth. Finally, it was observed that particles in the very middle of the center current may be carried directly to the mouth. Usually, these particles gain the highest velocity about a quarter of the way down the lophophore whereupon the speed decreased to zero in front of the mouth. 
A
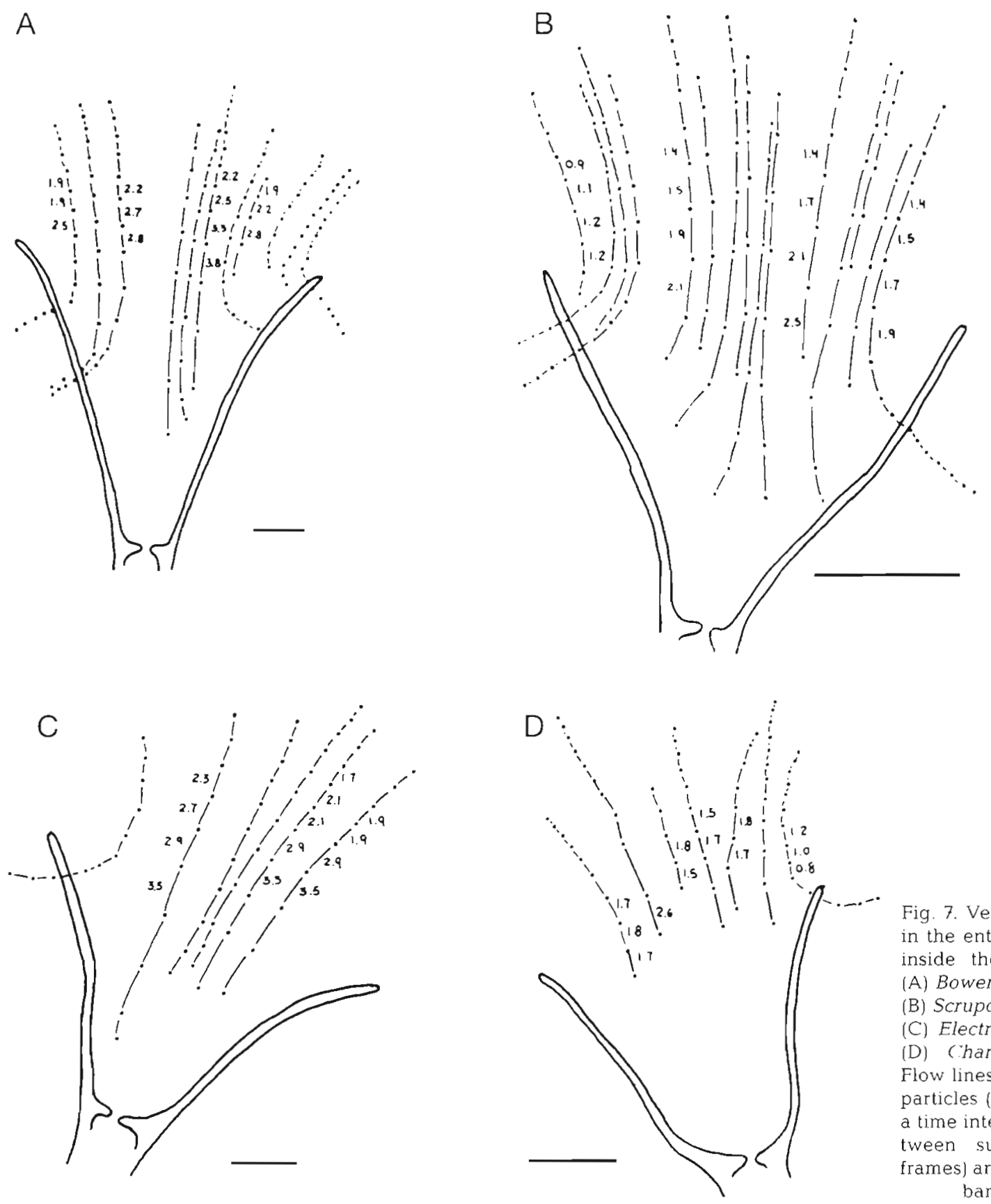

Fig. 7. Velocity distribution in the entrance region and inside the lophophore of (A) Bowerbankia imbricata, (B) Scrupocellaria scruposa, (C) Electra hastingsae and (D) Charteria papyracea. Flow lines and velocities of particles $\left(\mathrm{mm} \mathrm{s}^{-1}\right.$, based on a time interval of $0.02 \mathrm{~s}$ between subsequent video frames) are indicated. Scale bars $=1.00 \mu \mathrm{m}$

\section{Tentacle flicking}

In all species regular inward flicking of the tentacles was observed during feeding. Individual tentacle flicking ('individual flicking') as well as simultaneous flicking by all the tentacles of the lophophore ('collective flicking') were frequently seen. The flicking of the tentacles in Crisia eburnea, Celleporella hyalina, Flustrellidra hispida and Bowerbankia imbricata were analysed in detail. Recorded parameters for flicking in these 4 species are shown in Table 3. Dependent on species, the frequency of an individual tentacle flick $\left(f_{\text {ten }}\right)$, observed on one lophophore in each case, was between 0.17 and 0.71 flicks s${ }^{-1}$ while the frequency of collective flicking of all tentacles $\left(f_{\text {coll }}\right)$ was between 0.03 and 0.15 flicks $s^{-1}$. The duration of the active stroke $\left\{t_{a}\right\}$ of the single tentacle flick varied between 0.04 and $0.09 \mathrm{~s}$ during which period the tentacle tip travelled an inward distance $\left(d_{\mathrm{t}}\right)$ of 33 to $725 \mu \mathrm{m}$ with a tip velocity $\left(v_{\text {lip }}\right)$ between 0.6 and $10.7 \mathrm{~mm} \mathrm{~s}^{-1}$ The dis- 

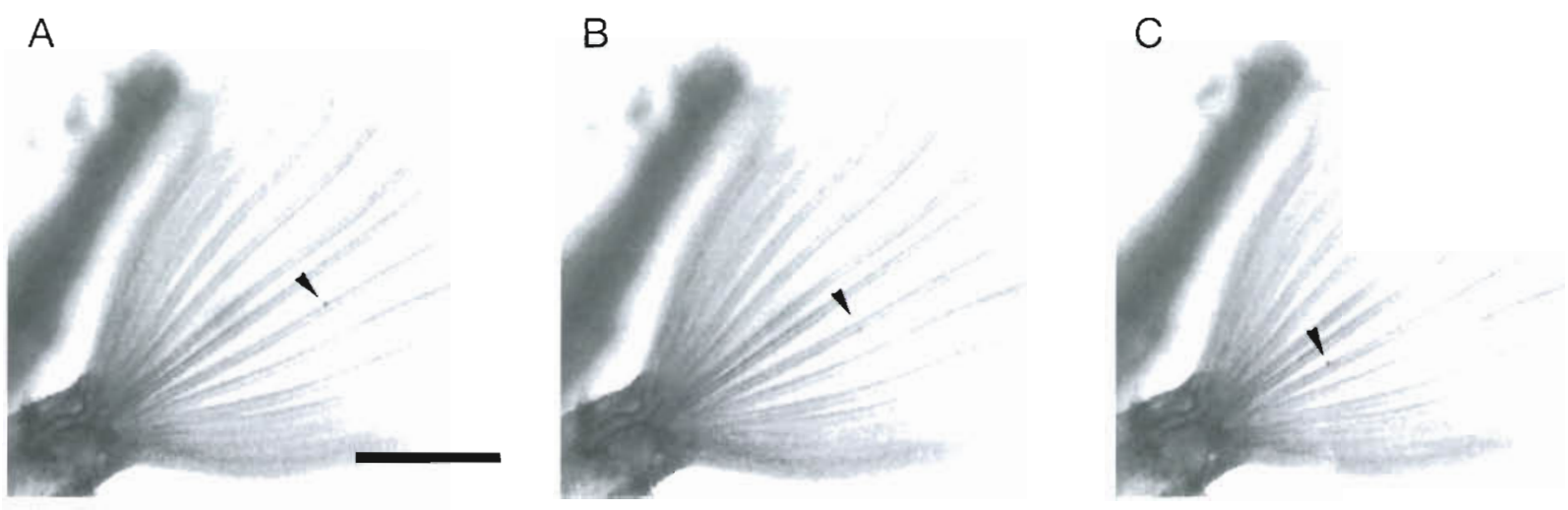

Fig. 8. Example of particle transport on a Flustrellidra hispida tentacle. Senes (A to C) of video graphic prints (0.04 s between prints $A$ and $B$, and $0.08 \mathrm{~s}$ between $B$ and $C$ ) showing downwards transport of an algal cell on a tentacle with a mean velocity of $2.5 \mathrm{~mm} \mathrm{~s}^{-1}$ Scale bar $=300 \mu \mathrm{m}$

tance from the tentacle tip to the flick-bending point $\left(L_{i j}\right)$ was measured to be between 44 and $554 \mu \mathrm{m}$. The duration of the recovery stroke $\left(t_{r}\right)$ of the flicking tentacles varied between 0.09 and $0.54 \mathrm{~s}$, which is 2.3 to 7.7 times longer than the active stroke period. In addition to these measurements, $B$. imbricata was also observed when food supply was increased. The flicking frequency approximately doubled, from $f_{t a n}=0.60 \pm 0.11$ and $f_{\text {coll }}=0.15 \pm 0.10$ flicks s ${ }^{-1}$ when 7000 algal cells were added (Table 4), to $f_{, \ldots,}=1.34 \pm 0.30$ and $f_{\text {coll }}=$ $0.27 \pm 0.05$ flicks $\mathrm{s}^{-1}$ when the concentration was further increased to $13 \times 10^{3}$ cells $\mathrm{ml}^{-1}$

\section{Filter mechanism, pumping rates and theoretical calculations}

The following data are assumed to apply for Celleporella hyalina: Clearance rate of $6 \mu \mathrm{m}$ particles $(F)=$ $0.17 \mathrm{ml} \mathrm{h}^{-1}$ zooid $^{-1}\left(20^{\circ} \mathrm{C}\right.$, Table 2$)$, number of tentacles $(N)=12$, length of tentacles $(L)=280 \mu \mathrm{m}$, radius of inhalant lophophore opening $(R)=150 \mu \mathrm{m}$ (present work), length of laterofrontal cilia $=20 \mathrm{~mm}$ (see 'Introduction').

\section{Filter mechanism}

Firstly, we assume that particles are retained from a $20 \mu \mathrm{m}$ wide zone defined by the length of the stiff laterofrontal cilia, with a mutual distance of $5 \mu \mathrm{m}$, forming a lattice-filter $(20 \times 5 \mu \mathrm{m})$ on each side of the tentacle. Next, if water with particles (>5 $\mu \mathrm{m}$ ) enters the filter-zone at a velocity of $1 \mathrm{~mm} \mathrm{~s}^{-1}$ (assumed on the basis of video recordings in the present work), then the volume of water cleared of particles per unit time (clearance rate) is: $F=0.1$ (velocity) $\times 0.0280$ (tentacle length) $\times 0.002$ (length of latcrofrontal cilia) $\times 2 \times 12$ (number of tentacles) $\times 60 \times 60=0.48 \mathrm{ml} \mathrm{h}^{-1}$ zooid $^{-1}$. This value is 2.8 times higher than the measured clearance of $0.17 \mathrm{ml} \mathrm{h}^{-1}$ zooid ${ }^{-1}$ However, the rigid laterofrontal cilia may not cut the main current at a right angle but rather at an angle of $60^{\circ}$ (Gilmour 1978 , Figs. $25 \& 28$ therein) This reduces the effective filter

Table 3. Tentacle-flicking parameters tor 4 species of ectoprocts based on observations of single lophophores. $f_{t+n}$ : Individual tentacle flickıngs; $f_{\text {coll }}$ : collective flickings of all tentacles; $d_{t}$ : distance travelled by tentacle tip durıng active stroke; $t_{a}$ : duration of active stroke; $t_{i}$ : duration of recovery stroke $v_{k ;}$ : tentacle tip velocity; $L_{i}$. distance of flick-bending point from tentacle tip. Mean values \pm SD are shown along with observation time (min) and number of observations ( $\mathrm{n}$ ) as indicated in brackets. All observations were made on ectoprocts exposed to a concentration of 7000 Rhinomonas reticulata cells $\mathrm{ml}^{-1}$

\begin{tabular}{|c|c|c|c|c|}
\hline & Crisia eburnea & Celleporella hyaina & Flustrellidra hispida & Bowerbankia imbricata \\
\hline$f_{\text {len }}\left(\right.$ flicks $\left.5^{-1}\right)$ & $0.68 \pm 0.21(2 \mathrm{~min})$ & $0.17 \pm 0.02(3 \mathrm{~min})$ & $0.71 \pm 0.18(5 \mathrm{~min})$ & $0.60 \pm 0.11(5 \mathrm{~min})$ \\
\hline$f_{\text {coll }}$ (flicks $s^{-1}$ ) & $0.03=0.05(2 \mathrm{~min})$ & $0.08 \pm 0.03(3 \mathrm{~min})$ & $0.05 \pm 0.02(5 \mathrm{~min})$ & $0.15 \pm 0.10(5 \mathrm{~min})$ \\
\hline$d_{t}(\mu m)$ & $33 \pm 17(12)$ & $46 \pm 18(17)$ & $725 \pm 171(7)$ & $197 \pm 94(8)$ \\
\hline$t_{\mathrm{d}}(\mathrm{s})$ & $0.06 \pm 0.03(12)$ & $0.04 \pm 0.01(17)$ & $0.07 \pm 0.01(7)$ & $0.09 \pm 0.04(8)$ \\
\hline$t_{5}(s)$ & $0.22 \pm 0.10(12)$ & $0.09 \pm 0.03(17)$ & $0.54 \pm 0.44(7)$ & $0.25 \pm 1.23(8)$ \\
\hline$v_{\text {lip }}\left(\mathrm{mm} \mathrm{s}^{-1}\right)$ & $0.6 \pm 0.3(12)$ & $1.3 \pm 0.7(17)$ & $10.7 \pm 2.9(7)$ & $2.4 \pm 1.2(8)$ \\
\hline$L_{i}(\mu \mathrm{m})$ & $44 \pm 22(5)$ & $97 \pm 13(8)$ & $554: \pm 8(6)$ & $135 \pm 27(6)$ \\
\hline
\end{tabular}


Table 4. Parameters for 15 species of truly/nearly radially symmetrical ectoproct lophophores: entrance water velocities (ınner entrance region $=v_{1}$; outer region $\left.=v_{2}\right)$, distance between tentacle tips $(D)$, radius of lophophore $(R)$, estimated pumping rate $(Q)$, number of tentacles in lophophore ( $N$ ), length of single tentacle $(L)$, total length of all tentacles ( $N L$ ), and tentacle length-specific pumping rate (water pumped per $\mathrm{cm}$ of tentacle, $Q_{T}$ ). Mean $\pm \mathrm{SD}$ are indicated for entrance velocities at $20^{\circ} \mathrm{C}$; all calculations are made according to the section 'Pumping rates' in 'Results'

\begin{tabular}{|c|c|c|c|c|c|c|c|c|c|}
\hline Species name and index number & $\begin{array}{c}v_{1} \\
\left(\mathrm{~mm} \mathrm{~s}^{-1}\right)\end{array}$ & $\begin{array}{c}V_{2} \\
\left(\mathrm{~mm} \mathrm{~s}^{-1}\right)\end{array}$ & $\begin{array}{c}D \\
(\mu \mathrm{m})\end{array}$ & $\begin{array}{c}R \\
(\mu \mathrm{m})\end{array}$ & $\left(\mathrm{ml} \mathrm{h}^{-1}\right.$ zooid $\left.^{-1}\right)$ & $N$ & $\begin{array}{c}L \\
(\mu \mathrm{m})\end{array}$ & $\begin{array}{c}N L \\
(\mathrm{~cm})\end{array}$ & $\begin{array}{c}Q_{\mathrm{T}} \\
\left(\mathrm{ml} \mathrm{h}^{-1} \mathrm{~cm}^{-1}\right.\end{array}$ \\
\hline Crisia eburnea \#1 & $1.78 \pm 0.31$ & $1.06 \pm 0.31$ & 79 & 100 & 0.14 & 8 & 200 & 0.16 & 0.88 \\
\hline Electra crustulenta $\# 2$ & $3.00 \pm 0.53$ & $2.04 \pm 0.71$ & 87 & 167 & 0.72 & 12 & 320 & 0.38 & 1.87 \\
\hline Electra hastingsae \#3 & $2.92 \pm 0.65$ & $1.81 \pm 0.43$ & 141 & 270 & 1.72 & 12 & 500 & 0.60 & 2.87 \\
\hline Electra pilosa $\# 4$ & $2.60 \pm 0.78$ & $2.36 \pm 0.53$ & 97 & 200 & 1.09 & 13 & 400 & 0.52 & 2.11 \\
\hline Membranipora membranacea $\# 5$ & $2.58 \pm 0.80$ & $1.29 \pm 0.39$ & 79 & 225 & 0.92 & 18 & 420 & 0.76 & 1.22 \\
\hline Chartella papyracea $\# 6$ & $1.58 \pm 0.39$ & $1.30 \pm 0.45$ & 85 & 175 & 0.47 & 13 & 300 & 0.39 & 0.55 \\
\hline Scrupocellaria reptans \#7 & $2.02 \pm 0.60$ & $1.13 \pm 0.38$ & 121 & 231 & 0.82 & 12 & 400 & 0.48 & 1.70 \\
\hline Scrupocellaria scrupea $\# 8$ & $2.38 \pm 0.49$ & $1.46 \pm 0.40$ & 94 & 150 & 0.43 & 10 & 270 & 0.27 & 1.59 \\
\hline Scrupocellaria scruposa $\# 9$ & $2.11 \pm 0.36$ & $1.50 \pm 0.32$ & 86 & 150 & 0.42 & 11 & 250 & 0.28 & 1.50 \\
\hline Bugula stolonifera \#10 & $2.36 \pm 0.46$ & $1.50 \pm 0.54$ & 89 & 185 & 0.66 & 13 & 330 & 0.43 & 0.65 \\
\hline Bicellariella ciliata \#11 & $1.07 \pm 0.30$ & $0.52 \pm 0.18$ & 72 & 150 & 0.17 & 13 & 200 & 0.26 & 0.64 \\
\hline Celleporella hyalina \#12 & $2.48 \pm 0.61$ & $1.40 \pm 0.55$ & 79 & 150 & 0.42 & 12 & 280 & 0.34 & 1.26 \\
\hline Alcyonidium gelatinosus $\# 13$ & $3.11 \pm 0.87$ & $1.35 \pm 0.79$ & 110 & 350 & 2.48 & 20 & 550 & 1.10 & 2.25 \\
\hline Flustrellidra hispida \#14 & $2.11 \pm 0.66$ & $1.75 \pm 0.52$ & 135 & 600 & 7.49 & 28 & 825 & 2.31 & 3.24 \\
\hline Bowerbankia imbricata \#15 & $2.59 \pm 0.23$ & $1.66 \pm 0.55$ & 188 & 300 & 1.93 & 10 & 700 & 0.70 & 2.75 \\
\hline
\end{tabular}

length of the laterofrontal cilia to $20 \times \cos 60^{\circ}=10 \mu \mathrm{m}$. Correcting for this in the above calculation gives a clearance of $0.24 \mathrm{ml} \mathrm{h}^{-1}$ zooid $^{-1}$, a value close to the experimentally measured clearance. This agreement, together with the retention efficiency spectrum shown in Fig. 5, supports the theory that a (mechanical) laterofrontal-filter is present in the ectoprocts.

\section{Pumping rates}

Knowing the incurrent water velocity $(v)$ and the cross sectional area $(A)$ of the inhalant opening (radius $=R$ ) of the lophophore, the volume flow (pumping rate $=Q$ ) may be determined as: $Q=v \times A$. However, video recordings of particle trajectories revealed that there is a velocity profile, the highest velocities being found in the central part of the lophophore. Therefore, the mean velocity $\left(v_{1}\right)$ through the central area of the feeding core $\left(A_{1}\right.$, radius $\left.=R / 2=r\right)$ and the velocity $\left(v_{2}\right)$ through the outer area $\left(A_{2}=A-A_{1}\right)$ may be used to estimate the value of $Q$. In Celleporella hyalina the following data have been applied.

$V_{1}=2.48 \mathrm{~mm} \mathrm{~s}^{-1}, V_{2}=1.40 \mathrm{~mm} \mathrm{~s}^{-1}, R=150 \mu \mathrm{m}, \mathrm{r}=R / 2$, $A_{1}=\pi \times \mathrm{r}^{2}=1.77 \times 10^{-4} \mathrm{~cm}^{2}, A_{2}=\pi \times(0.015)^{2}-A_{1}=$ $5.33 \times 10^{-4} \mathrm{~cm}^{2} Q_{1}=A_{1} \times V_{1}=4.45 \times 10^{-5} \mathrm{ml} \mathrm{s}^{-1} ; Q_{2}=$ $A_{2} \times V_{2}=7.43 \times 10^{-5} \mathrm{ml} \mathrm{s}^{-1} ; Q=Q_{1}+Q_{2}=11.88 \times 10^{-5} \mathrm{ml}$ $\mathrm{s}^{-1}=0.42 \mathrm{ml} \mathrm{h}^{-1}$

The total volume flow is thus estimated to be: $Q=$ $0.42 \mathrm{ml} \mathrm{h}^{-1}$ zooid $^{-1}$ This value minus the filtration rate (i.e. clearance rate of a $6 \mu \mathrm{m}$. particle $=F$ ) gives a measure of the volume of water flowing out between the tentacles without being filtered. In the present case $Q-F=0.42-0.16=0.26 \mathrm{ml} \mathrm{h}^{-1}$. Apparently, this shows that near $60 \%$ of the water pumped through the Celleporella hyalina lophophore by-passes the laterofrontal filter in the upper half of the tentacular crown.

The dimensions of feeding structures and water processing rates found for Celleporella hyalina and 14 other species of bryozoans (following the above method of calculation, using means values based on observations of 1 to 3 single lophophores) are collated in Table 4. It is notable that the pumping rate $(Q)$ varies among species, from $0.14 \mathrm{ml} \mathrm{h}^{-1}$ zooid $^{-1}$ in Crisia eburnea to $7.49 \mathrm{ml} \mathrm{h}^{-1}$ in Flustrellidra hispida. A number of parameters given in Table 4 have been plotted against each other in Figs. 11 to 13, and linear regression constants of ectoproct parameters are shown in Table 5. The pumping rates of all examined species ( $Q . \mathrm{mI} \mathrm{h}^{-1}$ zooid $^{-1}$ ) have been plotted as a function of the total lophophore tentacle length $(N L, \mathrm{~cm})$ in

Table 5. Linear regression constants of ectoproct parameters (shown in Table 4 ) on total length of all tentacles (NL, cm) according to $Y=a+b N L, v_{1}\left(\mathrm{~mm} \mathrm{~s}^{-1}\right)$ : maximum lophophore entrance velocity; $Q_{\uparrow}\left(\mathrm{ml} \mathrm{h} \mathrm{h}^{-1} \mathrm{~cm}^{-1}\right.$ of tentacle): tentacle length specific pumping rate; $D(\mu \mathrm{m})$ : tip-to-tip tentacle distance; $R$ ( $\mu \mathrm{m}\}$ : radius of lophophore

\begin{tabular}{|lcccr|}
\hline Regression & $a$ & $b$ & $r^{2}$ & \multicolumn{1}{c|}{$p$} \\
\hline$v_{1}$ on $N L$ & 2.193 & 0.199 & 0.037 & 0.50 \\
$Q_{\text {T }}$ on $N L$ & 1.031 & 1.072 & 0.451 & $<0.01$ \\
$D$ on $N L$ & 87 & 27 & 0.207 & 0.09 \\
$R$ on $N L$ & 91 & 226 & 0.960 & $<0.01$ \\
\hline
\end{tabular}




\section{A}

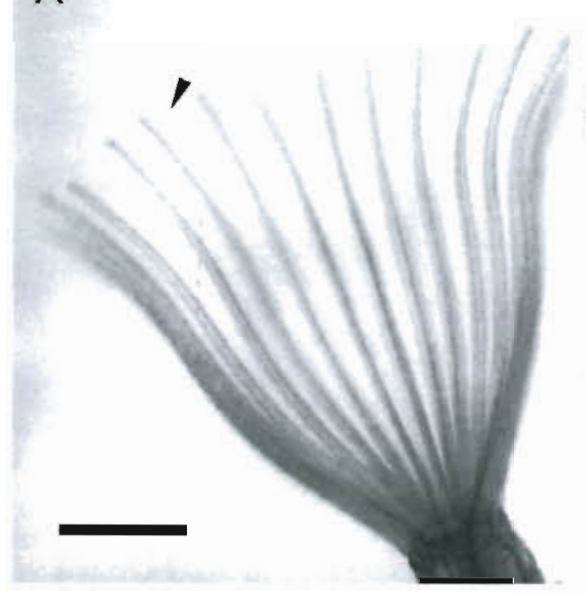

D

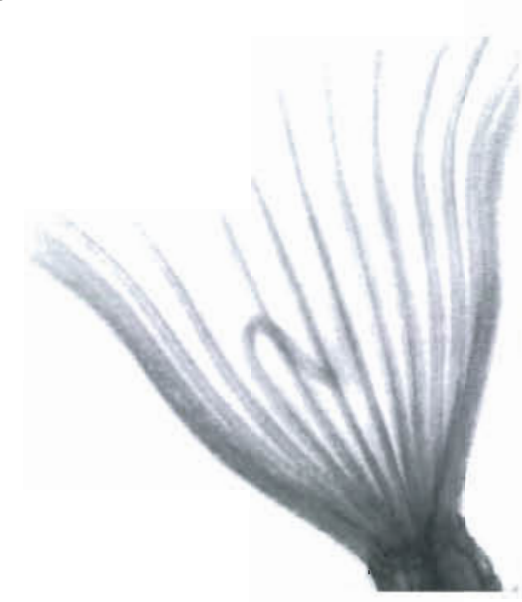

G

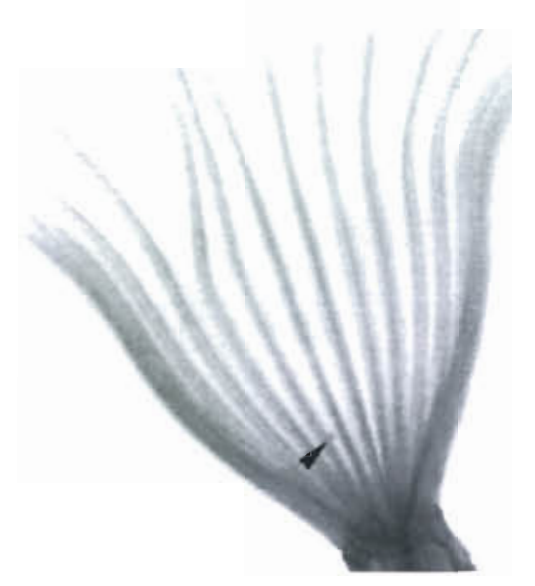

B

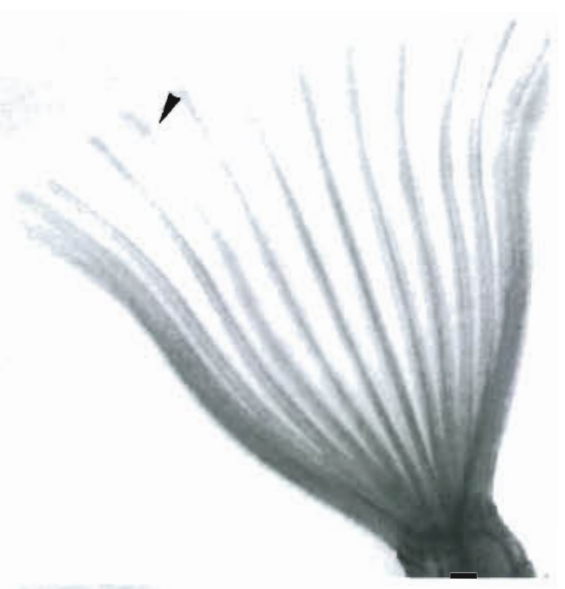

E

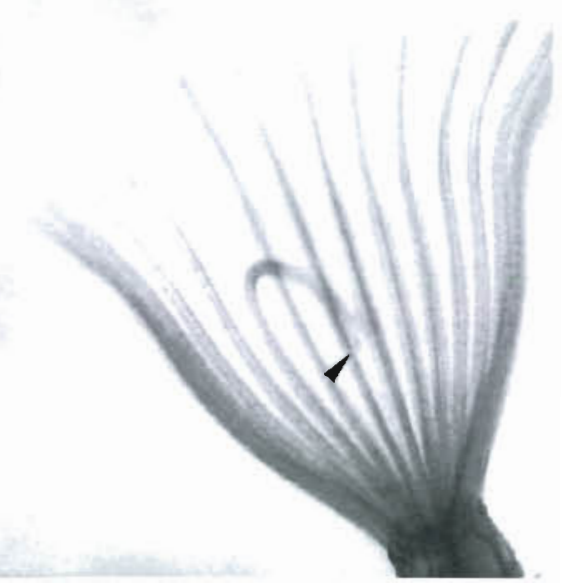

$\mathrm{H}$

C

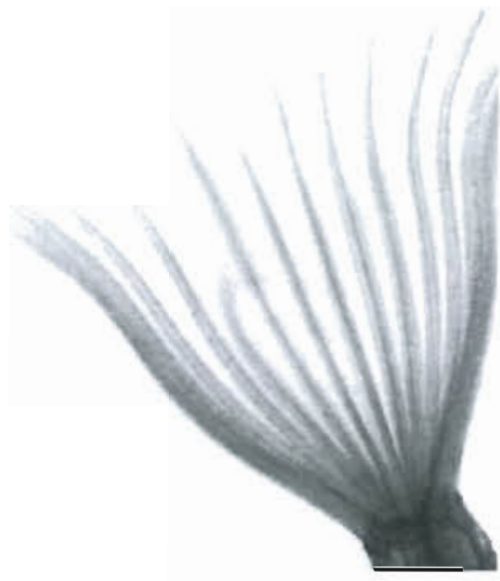

$\mathrm{F}$

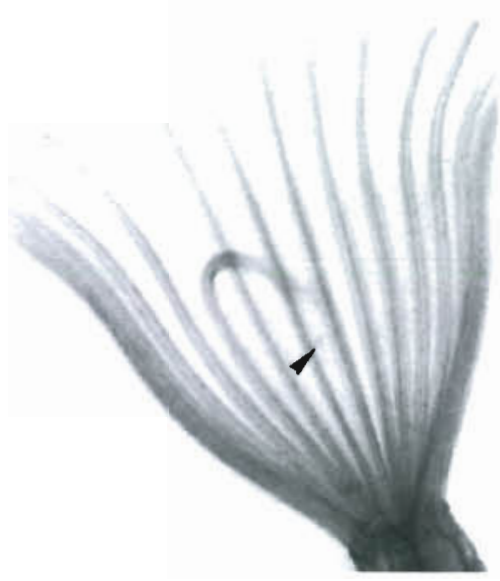

Fig. 9. Flustrellidra hispida. Video graphic prints showing a particle capture ( $A$; particle indicated by arrow) followed by a tentacle flick ( $B, C$ and $D_{i} 0.02$ s between prints), and a recovery phase ( $\mathrm{E}$ to $\mathrm{H}_{i} 0.1 \mathrm{~s}$ between prints). Scale bar $=200 \mu \mathrm{m}$

Fig. 11. It can be seen that the pumping rate of the zooids increases linearly with the total length of tentacles according to $Q=3.39 N L-0.704\left(\mathrm{r}^{2}=0.962\right)$. To judge from the slope ( $b \geqslant 1$ ) the pumping rate per unit of tentacle length increases with total tentacle length (and therefore lophophore size). This is also illustrated by the linear relationship between tentacle length specific pumping rate $\left(Q_{T}\right)$ and total tentacle length $(N L)$, see Table 5 . Thus, it is tempting to assume that the ciliary pump in small lophophores such as Crisia eburnea is relatively weak compared to large lophophores as found for example in Flustrellidra hispida. 
A

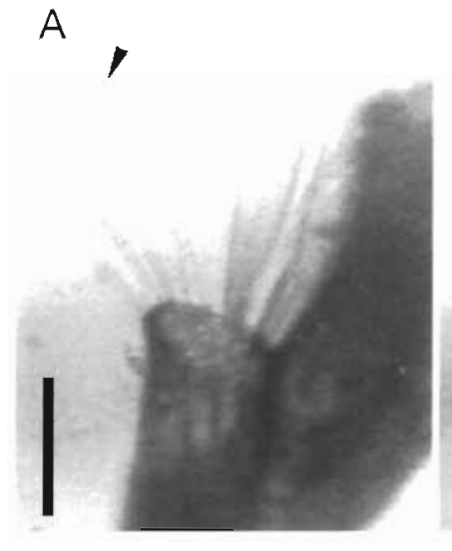

E
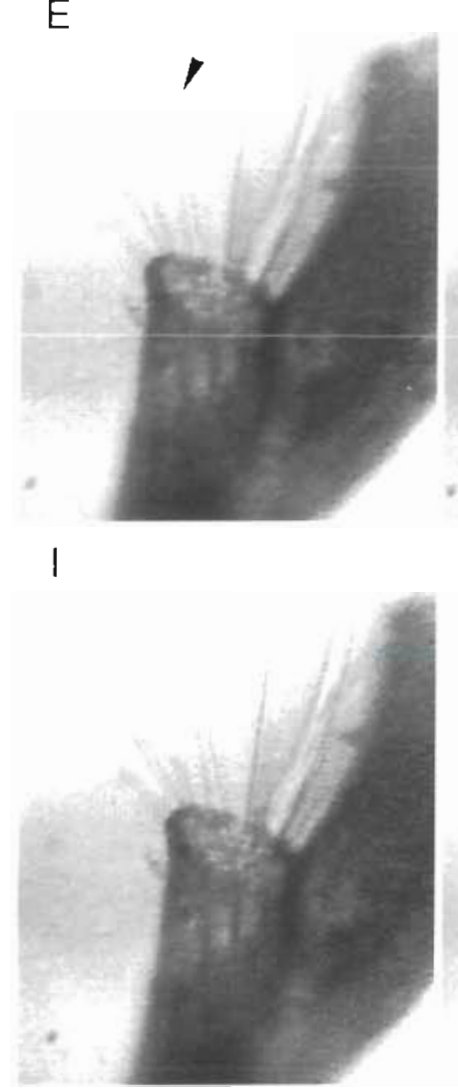

B

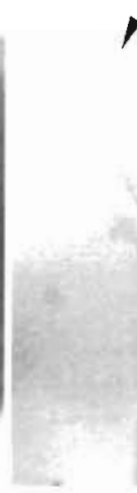

$\mathrm{F}$

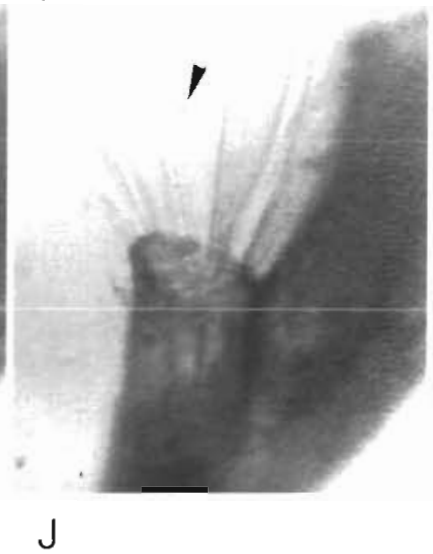

C

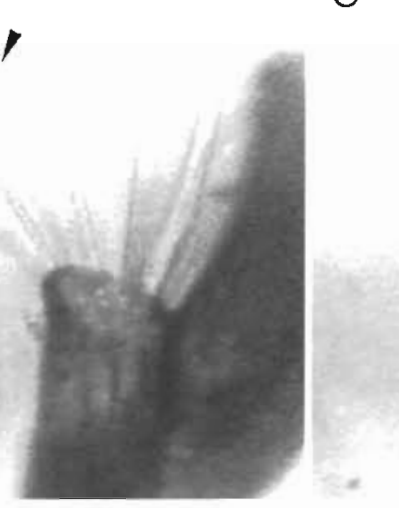

$\mathrm{G}$

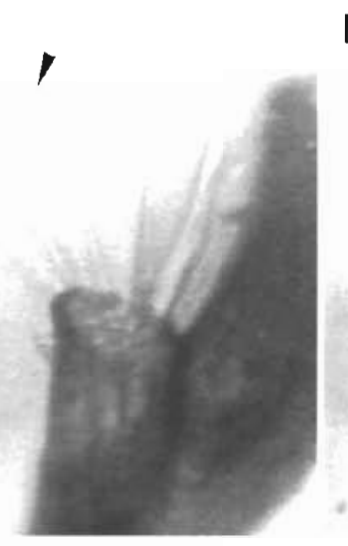

$\mathrm{H}$
D
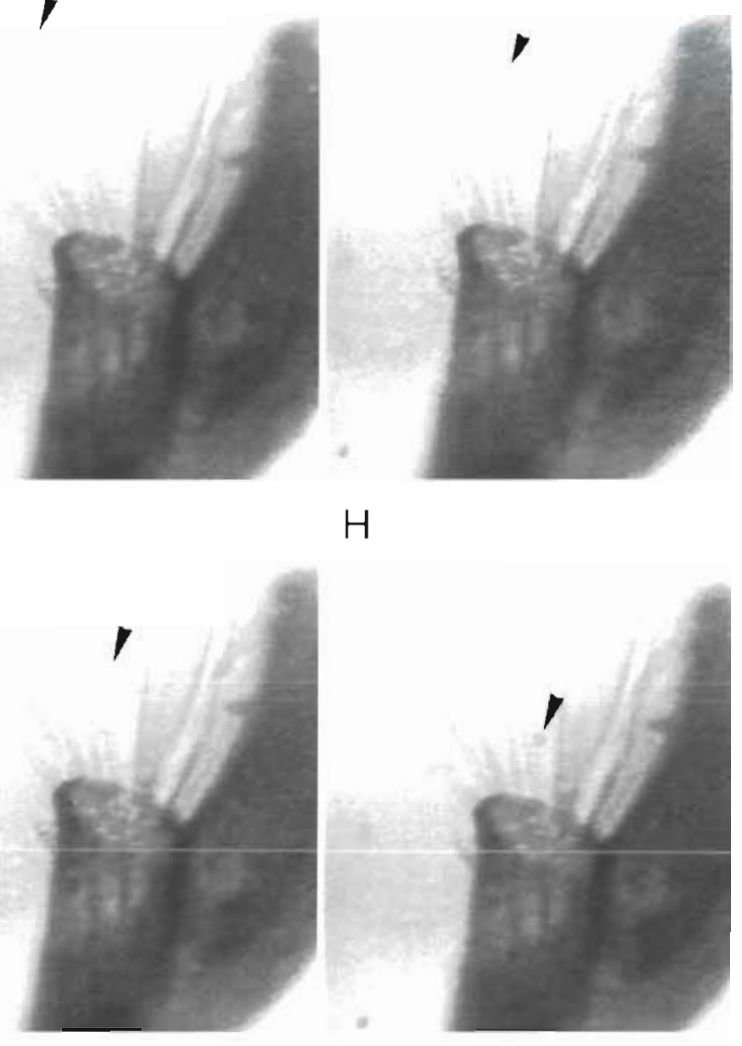

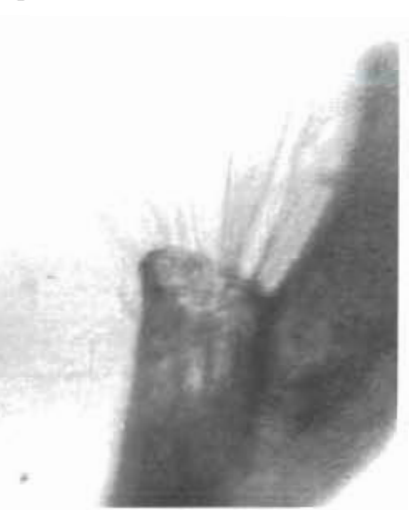

This may perhaps be due to fewer and/or shorter lateral cilia and lack of 'pump-supporting' frontal cilia in the former. Fig. 12 shows that both the radius and the number of tentacles of the lophophore increases with increasing length of the single tentacle. Further, Fig 13 shows that the radius of the lophophore increases with the number of tentacles. Fig. 12 illustrates how the number of tentacles has a tendency to increase with length of tentacle. This is however not true for Bowerbankia imbricata (\#15), which has only ten $700 \mu \mathrm{m}$ long tentacles and as a consequence exhibit the longest tip-to-tip distance recorded (Table 4).
Fig. 10. Crisia eburnea. Video graphic prints $(0.02 \mathrm{~s}$ between pictures) showing a particle capture (A) followed by a tentacle flick $(B, C$ and $D)$, and a recovery phase ( $E$ to J). The flucking brings the captured particle (indicated by arrow) into the central current of the lophophore which conveys ( $F$, $\mathrm{G}$ and $\mathrm{H}$ ) the particle downwards to the mouth. Scale bar =

$100 \mathrm{~mm}$

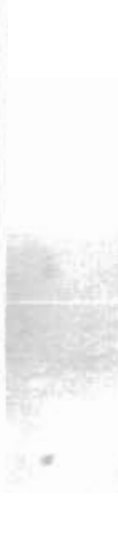

The maximum velocity $\left(v_{1}, \mathrm{~mm} \mathrm{~s}^{-1}\right)$ of particles in the middle of the entrance of the lophophore does not vary significantly with total length of tentacles and thus size of lophophore), see Table 5 . The mean values for all values of $v_{1}$ and $v_{2}$ were $2.31 \pm 0.53$ and $1.48 \pm$ $0.42 \mathrm{~mm} \mathrm{~s}^{-1}$, respectively. The circumference of the lophophore divided by the number of tentacles has been used to calculate the tip-to-tip tentacle distance shown in Table 5 . The mean tip-to-tip distance for the 15 species examined was found to be $103 \pm 38 \mu \mathrm{m}$ although there is a tendency toward increasing tip distance with increasing size of lophophore, see Table 5 . 


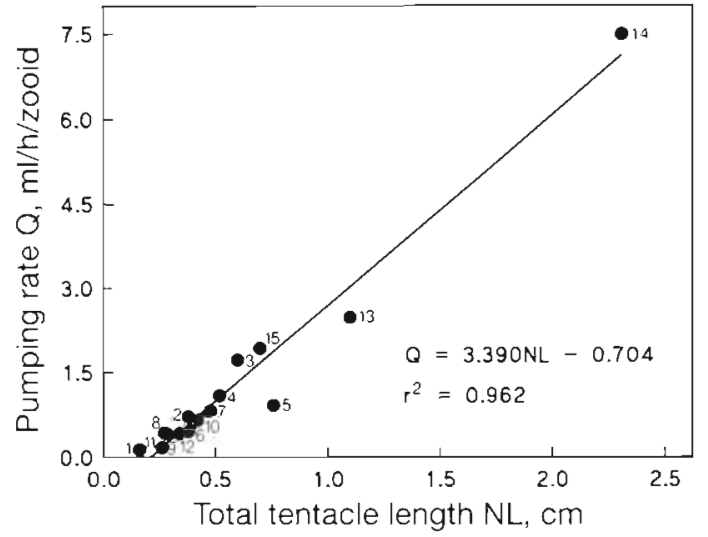

Fig. 11. Pumping rates of zooids $(Q)$ belonging to 15 different species of ectoprocts as a function of total tentacle length (NL). Based on data shown in Table 4
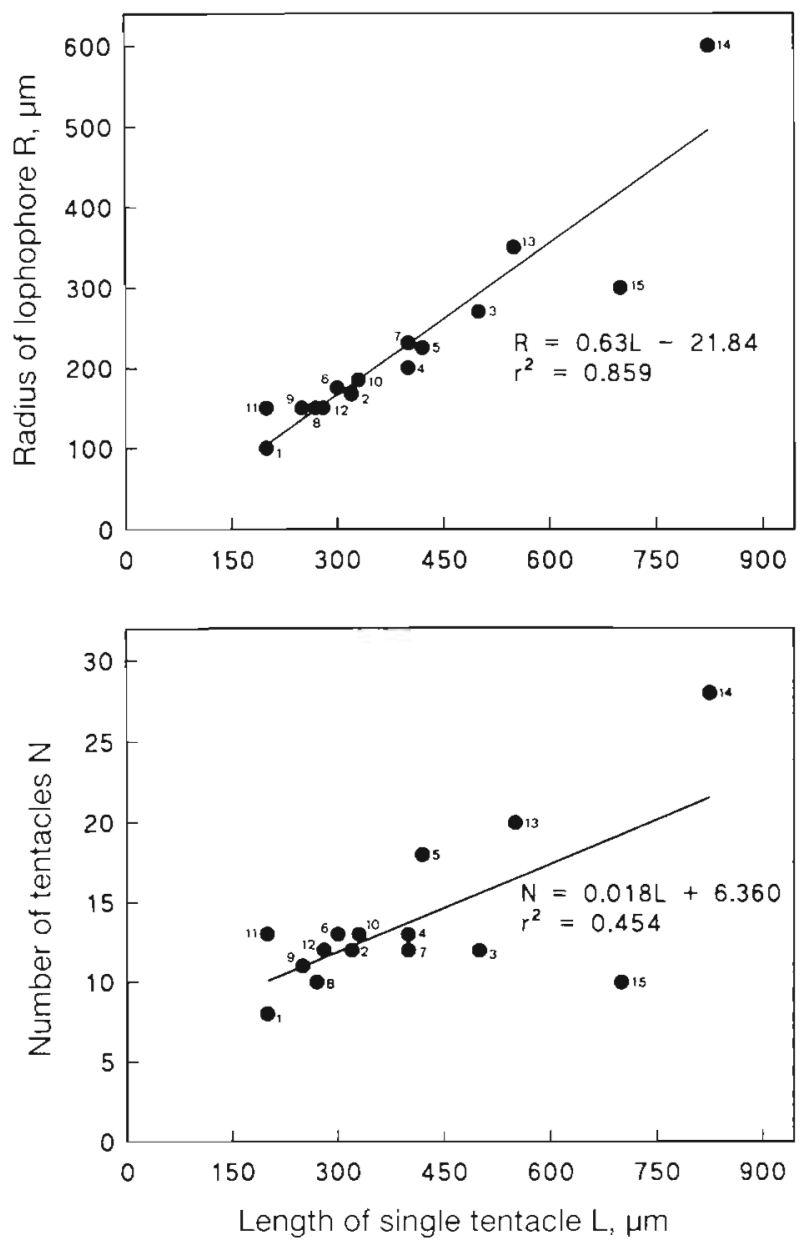

Fig. 12. Radius of lophophore $(R)$ and number of tentacles $(N)$ as a function of length of a single tentacle in 15 different species of ectoprocts shown in Table 4 . Numbers near data points refer to species index number in Table 1

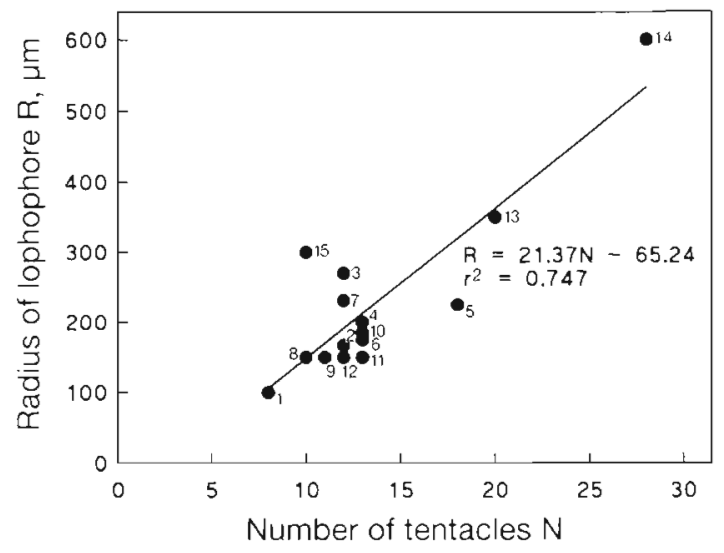

Fig. 13. Relationship between number of tentacles $(N)$ and radius of lophophore $(R)$. Numbers near data points refer to species number index in Table 1

\section{DISCUSSION}

\section{Clearance rates}

At very high algal concentration, clearance of Celleporella hyalina immediately ceased, but when a low algal concentration was established, the bryozoan slowly regained its original high clearance rate (Fig. 2A). This phenomenon can probably be explained by a rapid filling up of the gut ('satiation'), an interpretation supported by the fact that when the algal load was subsequently reduced the clearance capacity, which is continuously exploited at low concentrations, became more and more utilized, apparently simultaneous with evacuation of the gut. This 'satiation' phenomenon should not be ignored in feeding studies, as is also clear from the following.

Bullivant (1968a) was the first to quantify the feeding rate of an ectoproct. He applied the same clearance technique as used in the present work to a colony of the ctenostome bryozoan Zoobotryon verticillatum placed in a closed container with an algal suspension. By measuring the rate of change in different initial algal concentrations, Bullivant identified the 'satiation concentration', defined as the lowest concentration of particles at which the animal achieved a maxium ingestion rate. The clearance rates below satiation concentrations of 4 species of algae ranged from 0.15 to 1.05 (mean $0.44 \pm 0.21$ ) $\mathrm{ml} \mathrm{h}^{-1}$ zooid $^{-1}$.

The next research worker to measure clearance rates in 2 ectoprocts, Electra pilosa and Conopeum reticulum, was Menon (1974), who took note of Bullivant's 'satiation concentration' and performed all clearance experiments at relatively low initial concentrations of approximately 7500 Cryptomonas sp. cells $\mathrm{ml}^{-1}$ The 
mean clearance rate of E. pilosa was found to be $0.25 \pm$ $0.07 \mathrm{ml} \mathrm{h}^{-1}$ zooid $^{-1}$ at $18^{\circ} \mathrm{C}$. Recently, more clearance measurements have been performed on colonies of $E$. pilosa cultivated on pieces of glass (Riisgård \& Goldson unpubl.). Using Rhinomonas reticulata in initial concentrations of $2500 \mathrm{cells} \mathrm{ml}^{-1}$, they found that the clearance rate was $0.28 \mathrm{ml} \mathrm{h}^{-1}$ zooid $^{-1}$, in good agreement with Menon (1974). The clearance rate of particles $>6 \mu \mathrm{m}(F)$ may be compared to the higher pumping rate $(Q)$ of $1.09 \mathrm{ml} \mathrm{h}^{-1}$ zooid $^{-1}$ in the present work (Table 4). The ratio $F / Q=0.28 / 1.09=0.26$ shows that about $25 \%$ of the water pumped through the lophophore entrance may subsequently pass through the laterofrontal-filter.

Menon (1974) also studied the effect of temperature. In Fig. 14 the maximum clearance rates of Celleporella hyalina measured in the present work at different temperatures (Table 2) have been compared to clearance rates measured in Electra pilosa and C. reticulum at various temperatures by Menon (1974). The consistency of the data is satisfactory.

As stated above, a crucial factor which may highly influence the clearance rate is the algal concentration. We assume that $4 \times 10^{3}$ Rhinomonas reticulata cells $\mathrm{ml}^{-1}$ corresponds to $5 \mu \mathrm{g}$ chlorophyll a $\mathrm{l}^{-1}$ (Clausen \& Riisgård 1996), which is the median value applicable to Danish fjords and coastal waters between March and October (Sand-Jensen et al, 1994). This indicates that actively filter-feeding ectoprocts in nature seldom experience high 'satiation' algal concentrations resulting in reduced clearance rates. Apparently, this is also the case for Antarctic bryozoans which are filter feeding most of the time on nanoplankton. (2 to $20 \mu \mathrm{m}$ ) concentrations of only 80 to 100 cells $\mathrm{ml}^{-1}$ in the winter and up to 1500 cells $\mathrm{ml}^{-1}$ in the summer (Barnes \& Clarke 1994).

The chlorophyll a (chl a) concentration has been determined throughout 3 seasonal cycles in the Menai Strait by Blight et al. (1995), who analysed water samples collected at a depth of $1 \mathrm{~m}$ from St. George's pier at Menai Bridge, close to the collecting site of ectoprocts in the present work. One to 3 distinct chl a peaks were seen during spring and early summer (about 8 to $12 \mu \mathrm{g} \mathrm{chl} \mathrm{a}^{-1}$ ) followed by substantially lower values during the rest of the season. Thus, in 1993 the $\mathrm{chl}$ a concentrations remained low, near $1 \mu \mathrm{g}$ $\mathrm{l}^{-1}$ (equivalent to 800 Rhinomonas reticulata cells $\mathrm{ml}^{-1}$ ), for the rest of the year (except for a late summer diatom bloom which declined over the course of $2 \mathrm{wk}$ ).

The availability of phytoplankton in the lower intertidal zone in Port Erin Bay (Isle of Man, Northern Irish Sea) has recently been examined by Sanderson et al. (1996). At $2 \mathrm{~h}$ intervals over the full tidal cycle on $3 \mathrm{~d}$ in succession it was found that the mean chlorophyll a concentration varied over the course of the tidal cycle.

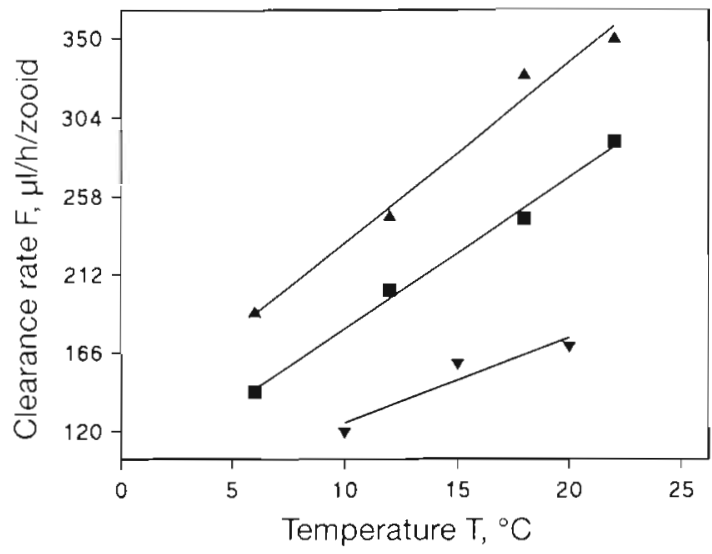

Fig. 14. Clearance rate $\left(F, \mu l \mathrm{~h}^{-1}\right.$ zooid $\left.^{-1}\right)$ as a function of temperature $\left(T,{ }^{\circ} \mathrm{C}\right)$ in 3 species of ectoprocts. Upper regression line: Electra pilosa, $F=8.91 T+91\left(r^{2}=0.993\right)$ (Menon 1974); middle line: Conopeum reticulum, $F=10.5 T+125\left(\mathrm{r}^{2}=0.984\right)$ (Menon 1974), bottom line: Celleporella hyalina, $F=5.00 \mathrm{~T}+$ $75\left(r^{2}=0.893\right)$ (present work)

ranging from about $16 \mu \mathrm{g} \mathrm{I}^{-1}$ at low tide to approximately $3 \mu \mathrm{g}^{-1}$ at high tide (mean $8 \pm 5 \mu \mathrm{g} \mathrm{l}^{-1}$ ). Incoming and receding tidal water was thus characterised by increased food availability, but whether this probably short-lived phenomenon is of regular occurrence and whether it is of significance for bryozoan feeding remains so far uncertain.

Filter-feeders are characterized by pumping large amounts of water in relation to the energy requirement of the animal. Thus, to obtain enough food the performance of filter-feeders must generally exceed $10 \mathrm{l}$ of water per ml of oxygen consumed (Jørgensen 1975). Hunter et al. (1996) have recently measured the oxygen uptake $(R)$ in Celleporella hyalina to be $2.2 \pm$ $1.5 \times 10^{-6} \mathrm{ml} \mathrm{O}_{2} \mathrm{~h}^{-1}$ (after correction of a printing error; R. N. Hughes \& A. Goldson pers. comm.). Using the clearance rate $(F)$ of $0.17 \times 10^{-3} \mathrm{l} \mathrm{h}^{-1}$ measured in the present work (Table 2), we found that $F / R=68 \mathrm{l}$ of water per $\mathrm{ml} \mathrm{O}_{2}$ consumed, which is within the range found for various groups of marine invertebrate suspension feeders with similar particle retention efficiency (Riisgård \& Larsen 1995, Thomassen \& Riisgård 1995). Applying the above $F$ and $R$ values, assuming $80 \%$ assimilation efficiency (AE) as in mussels (Clausen \& Riisgård 1996), and using the following conversion factors: $1 \mathrm{ml} . \mathrm{O}_{2} \mathrm{~h}^{-1}=5522 \mu \mathrm{J} \mathrm{s}^{-1}$ and Rhinomonas reticulata $=1.75 \mu \mathrm{J} \mathrm{cell}^{-1}$ (Clausen \& Risgård 1996), we found that the algal concentration $(C)$ necessary to cover the energy requirement was: $C=R /(F \times 0.8)=$

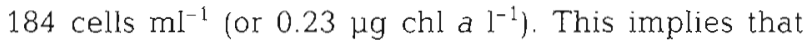
experimental work performed on ectoprocts using substantially higher algal concentrations than found in nature may not provide optimal feeding conditions, despite the fact that they supporting relatively good 
growth of colonies (Riisgård \& Goldson unpubl.). Further, we can predict that the minimal algal concentration causing maximum growth in $C$. hyalina may be found at a considerably lower algal concentration than hitherto used for cultivating ectoprocts.

\section{Particle capture and feeding currents}

The characteristic feature of particle capture, as was apparent from video recordings in the present work, was that when the path of a particle was altered from downwards, towards the mouth, to outwards between the tentacles, the particle impacted and stuck to a tentacle (Figs. 6 \& 7). In most species (but never in Crisia eburnea, which lacks frontal cilia) some of the trapped particles were seen to move down the tentacle surface towards the mouth presumably due to the action of frontal cilia (Fig. $9 \& 10$ ), but more frequently, another downward transport mechanism was involved. Tentacle flicking activity caused adherent particles to be conveyed back into the central lophophore current and to be carried further downwards, perhaps to be stopped and become stuck again to a tentacle (Fig. 8). These observations, supplemented with some simple theoretical calculations (see section 'Pumping rates'), support the assumption that a laterofrontal-filter strains the water while the central current, created by the special lophophore pump-design, and the action of flicking tentacles in co-operation clean the filter and transport the particles towards the mouth. Further, the measured particle retention efficiency (Fig. 5) supports the assumption that a mechanical laterofrontal-filter is present in the ectoprocts.

The literature dealing with the feeding process including capture of food particles and velocities of lophophore-generated currents has recently been reviewed by Mckinney (1990) and will not be summarised here. But in some cases, which may be crucial to a basic understanding of the feeding process, the present findings decisively differ from previous work The retention efficiency spectrum shown in Fig. 5 as well as the observations of the particle capture process support the impression that a mechanical laterofrontalfilter may be at work in the ectoprocts. Thus, frequent inward flicking of the tentacles (Table 3) seems to assist the transport of retrained particles to the downward central lophophore current. The frequency of flicking was dependent on both presence and concentration of algal cells. In Crisia eburnea the video recordings disclosed that apparently every single particle capture involved a tentacle flick, possibly triggered immediately after the particle was trapped by the laterofrontal-filter (Fig. 10). This illustrates that within the ectoprocts, which all use a common basic lophophore filter-feeding principle, several mechanisms may have evolved for transporting the 'mechanical-filter' trapped particles to the mouth. The significance of long, short or absent frontal cilia, as well as the mechanism for triggering both individual and collective tentacle flicking, await further examination.

The above description of the particle capture process does not involve a momentary reversal in the beat of lateral cilia as assumed by Strathmann $(1973,1982)$ and Strathmann \& McEdward (1986). However, Strathmann's description of tentacle flicks which transport particles to the central current the subsequent transfer of these particles by means of this current to a proximal part of the tentacle in 'a series of jumps' (Strathmann 1973 ) is in agreement with our observations. Other instances of unaccountable discrepancies between present findings and earlier works include the failure to demonstrate increasing feeding-current velocity as a function of both lophophore height and particle concentration as described by Best \& Thorpe $(1983,1986)$ Comparable feeding-current velocities of up to $2.5 \mathrm{~mm}$ $5^{-1}$ in Flustrellidra hispida as measured in the present work (Figs. 6\& 7, Table 4) were reported by Best \& Thorpe (1994). However, these velocities were apparently not later confirmed by Sanderson \& Thorpe (1996), who found that the maximum feeding-current velocity of 4 species of ectoprocts varied between $1.2 \mathrm{~mm} \mathrm{~s}^{-1}$ (Membranipora membranacea) to $1.4 \mathrm{~mm}$ $\mathrm{s}^{-1}$ (F. hispida) at $19.6^{\circ} \mathrm{C}$ and $2 \times 10^{5}$ algal cells $\mathrm{ml}^{-1}$. Further, Sanderson \& Thorpe (1996) measured feeding-current velocities generated by $F$. hispida at different temperatures. At a natural algal concentration of 5000 cells ml $\mathrm{m}^{-1}$ it was found that the feeding-current velocity was $0.95,1.04$ and $1.08 \mathrm{~mm} \mathrm{~s}^{-1}$ at 5,12 and $20^{\circ} \mathrm{C}$, respectively. Sanderson \& Thorpe (1996) did not take into account the variance in feeding-current across the diameter of the lophophore (cf. Figs. $6 \& 7$, Table 4 ; but see also Best \& Thorpe 1983, their Fig. 6). Therefore, the volume flow rates estimated by Sanderson \& Thorpe (1996) for 4 ectoprocts at different temperatures are likely to have been overestimated because the volume flow rates (i.e. pumping rates) were found by multiplying the cross-sectional area of the distal end of lophophore by the maximum feedingcurrent velocity. The same objection may apply to flow rates estimated for Himantozoum antarcticum by Sanderson et al. (1994). In the present work we have distinguished between mean velocities measured in the inner and the outer entrance region (Table 4) to take into account that the feeding-current varies across the diameter of the lophophore.

It is notable that most measurements made by Best $\&$ Thorpe $(1983,1986)$ and Sanderson \& Thorpe (1996) were performed at high concentrations of $10 \mu \mathrm{m}$ diameter cells of Tetraselmis suecica (up to $2 \times 10^{5}$ cells 
$\mathrm{ml}^{-1}$ ). Such high concentrations tend to disturb normal feeding behaviour, which is characterized by steadiness of pumping, full exploitation of the filtering potential and a well-defined frequency of tentacle flickings, dependent on algal concentration. At abnormally high algal concentrations ( $>3 \times 10^{4}$ Rhinomonas reticulata cells $\mathrm{ml}^{-1}$ ) we noticed violent, disorgamized flickings of the tentacles, frequent contractions of the lophophore and expulsions made by the 'pharynx suction-pump', which normally sucks food into the mouth by regular, rapid dilations of the pharynx without causing conspicuous countercurrents.

There is little information on the effects of suspended silt on ectoproct feeding (Best \& Thorpe 1996). But we never saw particles being 'propelled to the tips of the tentacles and discharged into the outgoing water currents by the frontal cilia' as described by Gilmour (1978), who exposed Membranipora sp. to a mixture of algal cells and Sephadex particles. It remains to be clarified how ectoprocts cope with inorganic silt particles, and the observations made by Gilmour (1978) may perhaps apply for that situation, i.e. sorting out inedible particles. If this is in fact the case, it may be difficult to interpret results obtained in experiments with inorganic particles. Thus, in Bugula neritina and B. stolonifera Okamura $(1987,1990)$ found disproportionate ingestion of polystyrene particles with diameters of 9.6, 14.6 and $19.1 \mu \mathrm{m}$ as well as flow velocitydependent variations in the ingestion rate of these particles. Unless postcapture selection takes place, these findings are irreconcilable with a fixed, almost $5 \mu \mathrm{m}$ width laterofrontal-filter as advocated in the pre. sent work.

Acknowledgements. H.U.R. was supported by a grant from the Danish Natural Research Counc1l (reg. no. 28-808) during his sabbatical stay at the School of Biological Sciences, University of Wales, Bangor (UWB). P.M. Was supported by a grant held by Prof. Roger N. Hughes (UWB), who collected many of the species used, generously supported the work and passed remarks on the manuscript. Thanks are due to Dr Claus Nielsen and Prof. P. S. Larsen for passing remarks on an early version of the manuscript and to the anonymous referees for improvements to the manuscript.

\section{LITERATURE CITED}

Atkuns D (1933) The cliary feeding mechanism of the entoproct Polyzoa, and a comparison with that of the ectoproct Polyzoa. Q J Microsc Sci 75:393-423

Barnes DKA. Clarke A (1994) Seasonal variation. in the feeding activity of four species of Antarctic bryozoan in relation to environmental factors. J Exp Mar Bıol Ecol 181: $117-133$

Best MA, Thorpe JP (1983) Effects of particle concentration on clearance rate and feeding current velocity in the marine bryozoan Flustrellidra hispida. Mar Biol 77:85-92

Best MA. Thorpe JP (1986) Effects of food particle concentra- tion on feeding current velocity in six species of marıne Bryozoa. Mar Biol 93:255-262

Best MA, Thorpe J (1994) Particle size, clearance rate and feeding efficiency in marina Bryozoa. In: Hayward PJ, Fyland JS, Taylor PD (eds) Biology and palaeobiology of bryozoans. Proceedings of the 9 th international bryozoology conference, University of Wales, Swansea, 1992. Olsen \& Olsen, Fredensborg 1994, p 9-14

Best MA, Thorpe JP (1996) Effect of suspended particulate matter (silt) on feeding activity of the intertidal ctenostomate bryozoan Flustrellidra hispida (Fabricius). In: Gordon DP, Smith AM, Grant-Mackie JA (eds) Bryozoans in space and time. Proceedings of the 10th international bryozoology conference, Wellington, New Zealand, 1995. National Institute of 1 'ater \& Atmospheric Research Ltd, Wellington, p 39-45

Blight ST, Bentley LT, Lefevre D, Robinson C, Rodrigues R, Rowlands J, Williams PJleB (1995) Phasing of autrotrophic and heterotrophic plankton metabolism in a temperate coastal ecos: stem. Mar Ecol Prog Ser 128:61-75

Bullivant JS (1968a) The rate of feeding of the bryozoan, Zoobotryon verticillatum. NZ J Mar Freshwater Res 2: $111-134$

Bullivant JS (1968b) The method of feeding of lophophorates (Bryozoa, Phoronida, Brachiopoda). NZ J Mar Freshwater Res 2:135-146

Cadman PS, Ryland JS (1996) The characters, reproduction, andi growih of Alcyonidum mylili Dalyell, 1848 (Cienostomatidal. In: Gordon DP, Smith AM, Grant-Mackle JA (eds) Bryozoans in space and time. Proceedings of the 10th international bryozoology conference, Wellington, New Zealand, 1995. National Institute of Water \& Atmospheric Research Ltd, Wellington, p 69-79

Clausen I, Riisgård H.U (1996) Growth, filtration and respiration in the mussel Mytilus edulis: no regulation of the filter-pump to nutritional needs. Mar Ecol Prog Ser 141. $37=45$

Gilmour THJ (1978) Ciliation and function of the foodcollectung and waste-rejecting organs of lophophorates. Can J Zool 56:2142-2155

Gordon DP (1974) Microarchitecture and function of the lophophore in the bryozoan Cryptosula pallasiana. Mar Biol 27:147-163

Gordon DP, Clark AG, Harper JF (1987) Bryozoa. In: Animal energetics, Vol 2. Academic Press, London, p 173-199

Hayward PJ, Ryland JS (1995) Handbook of the marine fauna of North-West Europe. Oxford University Press, Oxford

Hunter E, Hughes RN (1993) Effects of diet on life-history parameters of the marine bryozoan. Celleporella hyalina (L.). J Exp Mar Biol Ecol 167:163-177

Hunter $E_{1}$ Hughes RN, Goldson A (1996) Environmental and genetic control of somatic and sexual performance in Celleporella hyalina (L.). In: Gordon DP, Smith AM, Grant-Mackie JA (eds) Bryozoans in space and time. Proceedings of the 10th international bryozoology conference, Wellington, New Zealand, 1995. National Institute of Water \& Atmospheric Research Ltd, Wellington, p $149-156$

Jebram D (1979) Interrelations of nutrition, food uptake, and growth in bryozoans. In: Larwood GP, Abbott MB (eds) Advances in bryozoology. Systematics Association Special Volume No. 13, Academic Press, London, p 121-140

Jorgensen CB (1975) Comparative physiology of suspension feeding. Annu Rev Physiol 37:57-79

Lutaud G (1973) L'innervation du lophophore chez le Bryozoaire chilostome Electra pilosa (L.). Z Zellforsch 140: $21.7-234$ 
McKinney FK (1990) Feeding and associated colonial morphology in marine bryozoans. Rev Aquat Sci 2:255-288

Menon NR (1974) Clearance rates of food suspension and food passage rates as a function of temperature in two North-Sea bryozoans. Mar Biol 24:65-67

Mukai H, Terakado K, Reed CG (1997) Bryozoa. In: Harrison FW (ed) Microscopic anatomy of invertebrates, Vol 13. Wiley-Liss, New York, p 45-206

Muñoz MR, Cancino JM (1989) Consecuencias del tamaño colonial en la tasa metabólica de Cauloramphus spintferum (Bryozoa). Rev Chil Hist Nat 62:205-216

Nielsen C (1971) Entoproct life-cycles and the entoproct/ ectoproct relationship. Ophelia 9:209-341

Nielsen C (1987) Structure and function of metazoan ciliary bands and their phylogenetic significance. Acta Zool (Stockh) 68:202-262

Nielsen C (1995) Animal evolution. Interrelationships of the living phylla. Oxford University Press, Oxford

Novarno G (1992) Observations on Rhinomonas reticulata comb. nov. and and $R$. reticulata var. eleniana var. nov. (Cryptophyceae), with comments on the gencra Pyrenomonas and Rhodomonas. Nordic J Bot 11:243-252

Okamura B (1987) Particle size and flow velocity induce an inferred switch in bryozoan suspension-feeding behavior. Biol Bull (Woods Hole) 173:222-229

Okamura B (1990) Particle size, flow velocity, and suspensionfeeding by the erect bryozoans Bugula neritina and $B$. stolonifera. Mar Biol 105:33-38

Riisgård HU, Larsen PS (1995) Filter-feeding in marine macroinvertebrates: pump characteristics, modelling and energy cost. Biol Rev 70:67-106

Ryland JS (1976) Physiology and ecology of marine bryozoans. Adv Mar Biol 14:285-443

Sanderson WG, Harding SP, Thorpe JP (1996) An investıgation of the effects of tidal fluctuations on the availability of seston as food for intertidal Bryozoa. In: Gordon DP, Smith AM, Grant-Mackie JA (eds) Bryozoans in space and time. Proceedings of the 10th international bryoz.oology conference, Wellington, New Zealand, 1995. National. Institute of Water \& Atmospheric Research Ltd, Wellington, p 259-269

Sanderson WG, Thorpe JP (1996) Effects of temperature on the feeding activity of some temperate intertidal Bryozoa In: Gordon DP, Smith AM, Grant-Mackie JA (eds) Bryozoans in space and time. Proceedings of the 10th interna-

This article was submitted to the editor tional bryozoology conference, Wellington, New Zealand, 1995. National Institute of Water \& Atmospheric Research Ltd, Wellington, p 271-281

Sanderson WG, Thorpe JP, Clarke A (1994) A preliminary study of feeding rates in the Antarctic cheilostomate bryozoin Himantozoum antarctium. In: Hayward PJ, Ryland JS, raylor PD (eds) Biology and palaeobiology of bryozoans. Proceedings of the 9th international bryozoology conference, University of Wales, Swansea, 1992. Olsen \& Olsen, Fredensborg 1994, p 167-171

Sand-Jensen K, Nielsen SL, Borum J, Geertz-Hansen O (1994) Fytoplankton- og makrofytudviklingen i danske kystomrader (Phytoplankton and macrophyte development in Danısh coastal waters\}. Havforskning, Miljøstyrelsen no. 30 Miljoministeriet, Copenhagen (in Danish with Englısh summary)

Strathmann R (1973) Function of lateral cilia in suspension feeding lophophorates (Brachiopoda, Phoronida, Ectoprocta). Mar Biol 23:129-136

Strathmann RR (1982) Cinefilms of particle capture by an induced local change of beat of lateral cilia of a Bryozoan. J Exp Mar Biol Ecol 62:225-236

Strathmann RR, McEdward L (1986) Cyphonautes' ciliary sieve breaks a biological rule of inference. Biol Bull (Woods Hole) 171:694-700

Thomassen S, Riisgard HU (1995) Growth and energetics of the sponge Halichondria panicea. Mar Ecol Prog Ser 128:239-246

Thorpe JP, Clarke DRK, Best MA (1986) Natural variation in tentacle number in marine bryozoans and the possible effects of intraspecific and interspecific ecological competition for food. In: Nielsen C, Larwood GP (eds) Bryozoa: Ordovician to recent. Olsen \& Olsen, Frndensborg, Denmark, p 319-327

Wendt DE (1996) Effect of larval swimming duration on success of metamorphosis and size of the ancestrular lophophore in Bugula neritina (Bryozoa). Biol Bull (Woods Hole) 191:224-233

Will.mer P (1990) Invertebrate relationships. Patterns in animal evolution. Cambridge University Press, Cambridge

Winston JE (1977) Feeding in marine bryozoans. In: Woollacott RM, Zimmer RL (eds) Biology of bryozoans. Academic Press, New York, p 233-271

Winston JE (1978) Polypide morphology and feeding behavior in marine ectoprocts. Bull Mar Sci 28:1-31

Manuscript recelved: March 27, 1997

Revised version accepted: June 10,1997 